Southern Illinois University Carbondale OpenSIUC

Publications

Department of Civil and Environmental

Engineering

$6-2018$

\title{
Partial-Span Live Loading Effects on the Design of Multi-Story Multi-Bay Steel Moment Frames
}

Jen-kan Kent Hsiao

hsiao@engr.siu.edu

Follow this and additional works at: http://opensiuc.lib.siu.edu/cee_pubs

This material may be downloaded for personal use only. Any other use requires prior permission of the American Society of Civil Engineers. This material may be found at https://ascelibrary.org/doi/ abs/10.1061/\%28ASCE\%29SC.1943-5576.0000387

\section{Recommended Citation}

Hsiao, Jen-kan K. "Partial-Span Live Loading Effects on the Design of Multi-Story Multi-Bay Steel Moment Frames." Practice Periodical on Structural Design and Construction Volume 23, No. 4 (Jun 2018): 04018020 1-14. doi:10.1061/(ASCE)SC.1943-5576.0000387.

This Article is brought to you for free and open access by the Department of Civil and Environmental Engineering at OpenSIUC. It has been accepted for inclusion in Publications by an authorized administrator of OpenSIUC. For more information, please contact opensiuc@lib.siu.edu. 


\title{
Partial-Span Live Loading Effects on the Design of Multi-Story Multi-Bay Steel Moment Frames
}

\author{
J. KENT HSIAO, Ph.D., P.E., S.E., F.ASCE ${ }^{1}$
}

\begin{abstract}
A critical live load pattern is the live load pattern which will produce the maximum axial force and/or bending moment in a structural member under consideration. Structural engineers commonly select the critical live load pattern from full-span live load patterns rather than partial-span live load patterns. In order to identify the most critical live load pattern, a threestory, two-bay steel moment frame design example is presented in this paper. In this design example, both first-order and second-order analyses are used for the determination of the required strength of the columns, while the effective length method is used for the determination of the design strength of the columns. The results of the example indicate that the effects caused by partial-span live load patterns are more critical than those caused by full-span live load patterns, not only in the computation of the required strength of the structural members, but also in the calculation of the maximum lateral displacement of the entire frame.
\end{abstract}

Keywords: Axial forces; Deflection; Effective length; Lateral forces; Live loads; Steel frames.

${ }^{1}$ Professor, Department of Civil and Environmental Engineering, Southern Illinois University Carbondale, Carbondale, IL 62901. E-mail: hsiao@engr.siu.edu 


\section{Introduction}

For the design of a structural member in a moment frame, the live load pattern must be varied to determine the maximum particular force in the structural member. For example, the live load pattern shown in Fig. 1(a) is commonly used by structural engineers to maximize the axial compressive force in column A-B. On the other hand, the live load pattern shown in Fig. 1(b) is commonly used by structural engineers to maximize the end moment in column A-B. Fig. 1(a) shows that the uniformly distributed live load is placed over the entire length of all beams directly connected to the column on all floors supported by the column A-B. The checkerboard pattern of live load shown in Fig. 1 (b) maximizes the end moment at the top of column A-B. However, the associated axial force in the column A-B shown in Fig. 1(b) is only about one-half of that shown in Fig. 1(a). The method used to identify the critical live load patterns in order to determine the maximum axial force and/or moment in a column was discussed by Leet and Uang (2002).

\section{Partial-Span Live Loading}

The live load patterns shown in Figs. 1(a and b) are full-span load patterns. In a full-span load pattern, the uniformly distributed live load is placed over the entire length of the loaded beams. If the uniformly distributed live load is placed over only a portion of the beam, as shown in Fig. 2(a), the load pattern is called a partial-span load pattern. Fig. 2(a) shows that due to the unsymmetrical load on the beam, the frame undergoes sidesway. The analysis of the unsymmetrically loaded frame shown in Fig. 2(a) can be carried out by introducing a temporary restraint to prevent the frame from translating as shown in Fig. 2(b); the sway force [which has the same magnitude but is opposite in direction of the holding force shown in Fig. 2(b)] is then 
applied to the frame, as shown in Fig. 2(c). The partial-span loading effects on the axial forces and bending moments of the exterior column A-B in multi-bay moment frames, as well as the deflections of the entire frames, are presented in Fig. 3. It clearly indicates that the partial-span loading effects on the deflection of the entire frame become more significant if there are more partial-span loaded bays in the same story. In order to investigate the significance of the partialspan loading effects, a two-bay, three-story steel moment frame design example is demonstrated in this paper.

\section{Design Criteria for W-Shape Members Subject to Flexure and Compression}

The design interaction equations for doubly and singly symmetric members subject to flexure and compression are given by AISC Specification H 1.1 (AISC 2010) (Copyright (C) American Institute of Steel Construction. Reprinted with permission. All rights reserved.) as:

when $\frac{P_{r}}{P_{c}} \geq 0.2, \quad \frac{P_{r}}{P_{c}}+\frac{8}{9}\left(\frac{M_{r x}}{M_{c x}}+\frac{M_{r y}}{M_{c y}}\right) \leq 1.0$

when $\frac{P_{r}}{P_{c}}<0.2, \quad \frac{P_{r}}{2 P_{c}}+\left(\frac{M_{r x}}{M_{c x}}+\frac{M_{r y}}{M_{c y}}\right) \leq 1.0$

where $P_{r}=$ the required axial compressive strength; $P_{c}=$ the design axial compressive strength; $M_{r}=$ the required flexural strength; and $M_{c}=$ the design flexural strength.

Referring to Fig. 4, the required second-order axial strength, $P_{r}$, and flexural strength, $M_{r}$, of the beam-column can be determined using Eqs. (3) and (4) [AISC Specification Formulas (A8-2) and (A-B-1)] (Copyright (C) American Institute of Steel Construction. Reprinted with permission. All rights reserved.), respectively:

$P_{r}=P_{n t}+B_{2} P_{l t}$ 
$M_{r}=B_{1} M_{n t}+B_{2} M_{l t}$

where $P_{n t}=$ the first-order axial force with the structure restrained against lateral translation; $P_{l t}=$ the first-order axial force due to lateral translation of the structure only; $M_{n t}=$ the first-order moment with the structure restrained against lateral translation; $M_{l t}=$ the first-order moment due to lateral translation of the structure only; $B_{1}=$ the non-sway moment magnifier; and $B_{2}=$ the sway moment magnifier.

Per AISC Specification Formula (A-8-3) (Copyright (C) American Institute of Steel Construction. Reprinted with permission. All rights reserved.), the non-sway moment magnifier, $B_{1}$, can be computed as:

$B_{1}=\frac{C_{m}}{1-\frac{\alpha P_{r}}{P_{e 1}}} \geq 1$

where $\alpha=1.0$ for the Load and Resistance Factor Design (LRFD); $C_{m}=$ the factor in the nonsway moment magnifier; $P_{e 1}=$ the elastic critical buckling strength of the column in the plane of bending. Note that the required axial compressive strength, $P_{r}$, in Eq. (5) can be computed as $P_{r}$ $=P_{n t}+P_{l t}$.

According to AISC Specification Formula (A-8-4) (Copyright (C) American Institute of Steel Construction. Reprinted with permission. All rights reserved.), the factor $C_{m}$ for beam-columns with no transverse loads between supports in the plane of bending can be defined as:

$C_{m}=0.6-0.4\left(M_{1} / M_{2}\right)$

where $M_{1}=$ the smaller end moment; $M_{2}=$ the larger end moment; and $M_{1} / M_{2}=$ the absolute ratio of bending moment at the ends of the beam-column; the ratio is negative if bent in single curvature and positive if bent in reverse curvature. 
Also, according to the AISC Specification Formula (A-8-5) (Copyright (C) American Institute of Steel Construction. Reprinted with permission. All rights reserved.), the elastic critical buckling strength of the beam-column in the plane of bending, $P_{e 1}$, can be defined as:

$$
P_{e 1}=\frac{\pi^{2} E I^{*}}{\left(K_{1} L\right)^{2}}
$$

where $E I^{*}=E I$ for the effective length and first-order analysis methods; $E=$ the modulus of elasticity of steel $=29,000 \mathrm{ksi}(200000 \mathrm{MPa}) ; I=$ the moment of inertia in the plane of bending; $\mathrm{L}=$ the length of the member; and $K_{1}=$ the effective length factor in the plane of bending, determined based on the assumption that lateral translation at the member ends is absent, which is set equal to 1.0, unless analysis justifies a smaller value.

Per AISC specification Formula (A-8-6) (Copyright (C) American Institute of Steel Construction. Reprinted with permission. All rights reserved.), the sway moment magnifier, $B_{2}$, can be computed as follows:

$$
B_{2}=\frac{1}{1-\frac{\alpha P_{\text {story }}}{P_{\text {e story }}}} \geq 1
$$

where $\alpha=1.0$ for LRFD; $P_{\text {story }}=$ the total vertical load supported by the story; $P_{\text {e story }}=$ the elastic critical buckling strength for the story in the direction of translation being considered, which can be determined using Eq. (9) per AISC Specification Formula (A-8-7) (Copyright (C) American Institute of Steel Construction. Reprinted with permission. All rights reserved.):

$$
P_{e_{\text {story }}}=R_{M}\left(\frac{H L}{\Delta_{H}}\right)
$$

where $L=$ the story height; $\Delta_{H}=$ the first-order interstory drift due to lateral forces; $H=$ the story shear produced by the lateral forces used to compute $\Delta_{H}$; and 
$R_{M}=1-0.15\left(P_{m f} / P_{\text {story }}\right)$

where $P_{m f}=$ the total vertical load in columns in the story that are part of moment frames in the direction of translation being considered.

Note that in order to account for initial geometric imperfections of columns, notional loads shall be applied as lateral loads at all levels. According to AISC Specification Formula (C2-1) (Copyright (C) American Institute of Steel Construction. Reprinted with permission. All rights reserved.), the magnitude of the notional loads shall be:

$N_{i}=0.002 \alpha Y_{i}$

where $\alpha=1.0$ for LRFD; $N_{i}=$ the notional load applied at level $i$; and $Y_{i}=$ the gravity load applied at level $i$ from load combinations.

It is permissible to apply the notional load, $N_{i}$, only in gravity-only load combinations if $B_{2} \leq 1.7$ in all stories.

AISC Specification Table B4.1a specifies that the limiting $b_{f} / 2 t_{f}$ and $h / t_{w}$ ratios are $0.56 \sqrt{E / F_{y}}$ and $1.49 \sqrt{E / F_{y}}$, respectively, for non-slender w-shape compression elements subject to axial compression (where $b_{f}=$ the flange width; $t_{f}=$ the flange thickness; $h=$ the clear distance between flanges less the fillet or corner radius for rolled shapes; and $t_{w}=$ the web thickness). Also, according to AISC Specification E3 (Copyright (C) American Institute of Steel Construction. Reprinted with permission. All rights reserved.), the design axial compressive strength, $P_{c}$, of a non-slender w-shape compression member can be computed using Eq. (12):

$P_{c}=\phi_{c} P_{n}=\phi_{c} F_{c r} A_{g}$

where $\phi_{c}=$ the resistance factor for the compression member ( 0.9 for LRFD); $A_{g}=$ the gross area of the member; and $F_{c r}=$ the critical stress in compression. 
The critical stress in compression [AISC Specification Formulas (E3-2) and (E3-3)] (Copyright (C) American Institute of Steel Construction. Reprinted with permission. All rights reserved.) can be determined as follows:

$$
\begin{array}{ll}
F_{c r}=\left[0.658^{\frac{F_{y}}{F_{e}}}\right] F_{y} \quad \text { when } \frac{F_{y}}{F_{e}} \leq 2.25 \\
F_{c r}=0.877 F_{e} \quad \text { when } \frac{F_{y}}{F_{e}}>2.25
\end{array}
$$

where $F_{e}$ is the elastic buckling stress, which can be determined [AISC Specification Formula (E3-4)] (Copyright $@$ C American Institute of Steel Construction. Reprinted with permission. All rights reserved.) as:

$$
F_{e}=\frac{\pi^{2} E}{\left(\frac{K L}{r}\right)^{2}}
$$

where $K=$ the effective length factor; $L=$ the laterally unbraced length of the member; and $r=$ the governing radius of gyration about the axis of buckling.

The effective length factor, $K$, can be determined from the "Alignment Chart SideswayUninhibited (Moment Frame)" presented in AISC Specification Fig. C-A-7.2 or using Eq. (16) (Dumonteil 1992):

$$
K=\sqrt{\frac{1.6 G_{t o p} G_{b o t}+4.0\left(G_{t o p}+G_{b o t}\right)+7.5}{\left(G_{t o p}+G_{b o t}\right)+7.5}}
$$

in which the restraint factor at the top or the bottom of a column can be computed as

$$
G=\frac{\sum\left(\frac{I}{L}\right)_{\text {columns }}}{\sum\left(\frac{I}{L}\right)_{\text {beams }}}
$$


The subscripts top and bot in Eq. (16) refer to the joints at the top and bottom ends of the column being considered. The symbol $\Sigma$ in Eq. (17) indicates a summation of all members rigidly connected to that joint and located in the plane in which buckling of the column is being considered. Note that $G_{b o t}$ may be taken as 10 for practical designs for column bases supported by, but not rigidly connected to, a footing or foundation.

For a structural system with leaning columns, the effective length factor shall be modified using a leaning column amplifier (AISC 2006; Vinnakota 2006) as shown in Eq. (18):

$K_{m}=($ leaning column amplifier $) K=\left(\sqrt{1+\frac{\sum P_{\text {leaning }}}{\sum P_{\text {stability }}}}\right) K$

where $\Sigma P_{\text {leaning }}=$ the summation of the gravity loads supported by the leaning columns; and $\Sigma P_{\text {stability }}=$ the summation of the gravity loads supported by the stability columns.

Note that the use of the effective length method shall be limited to a ratio of maximum secondorder drift to maximum first-order drift in all stories equal to or less than 1.5 (i.e., $B_{2} \leq 1.5$ ).

AISC Specification Table B4.1b specifies that the limiting $b_{f} / 2 t_{f}$ and $h / t_{w}$ ratios are $0.38 \sqrt{E / F_{y}}$ and $3.76 \sqrt{E / F_{y}}$, respectively, for compact w-shape compression elements subject to flexure. The design flexural strength about the $x$-axis, $M_{c x}$, of a compact w-shape compression member (AISC Specification F2) (Copyright (C) American Institute of Steel Construction. Reprinted with permission. All rights reserved.) can be computed as follows:

when $L_{b} \leq L_{p}, \quad M_{c x}=\phi_{b} M_{n x}=\phi_{b} M_{p x}$

when $L_{p}<L_{b} \leq L_{r}, \quad M_{c x}=\phi_{b} M_{n x}=C_{b}\left[\phi_{b} M_{p x}-\phi_{b} B F\left(L_{b}-L_{p}\right)\right] \leq \phi_{b} M_{p x}$ 
when $L_{b}>L_{r}, \quad M_{c x}=\phi_{b} M_{n x}=\phi_{b}\left[\frac{C_{b} \pi^{2} E}{\left(\frac{L_{b}}{r_{t s}}\right)^{2}} \sqrt{1+0.078 \frac{J c}{S_{x} h_{o}}\left(\frac{L_{b}}{r_{t s}}\right)^{2}}\right] S_{x} \leq \phi_{b} M_{p x}$

where $L_{b}=$ the lateral unbraced length of compression flange; $L_{p}=$ the limiting laterally unbraced length for full plastic bending capacity; $\phi_{b}=$ the resistance factor for the flexural member ( 0.9 for LRFD); $M_{n x}=$ the nominal flexural strength about the $x$-axis; $M_{p x}=$ the plastic bending moment about the $x$-axis; $L_{r}=$ the limiting laterally unbraced length for inelastic lateral-torsional buckling; $C_{b}=$ the moment gradient factor for the lateral-torsional buckling strength; $B F=\mathrm{a}$ factor that can be used to calculate the flexural strength for the unbraced length $L_{b}$ between $L_{p}$ and $L_{r} ; r_{t s}=$ the effective radius of gyration used in determining $L_{r} ; J=$ the torsional constant for a section; $c=1$ for doubly symmetric I-shapes ; $S_{x}=$ the elastic section modulus with respect to $x$-axis; and $h_{o}=$ the distance between flange centroids.

The values of $L_{p}, L_{r}, \phi_{b} M_{p x}$, and $\phi_{b} B F$ are calculated and are listed in the AISC Steel Construction Manual (AISC 2011) for W sections.

The moment gradient factor for lateral-torsional buckling strength, $C_{b}$, can be determined using Eq. (22) [AISC Specification Formula (C-F1-1)] (Copyright C) American Institute of Steel Construction. Reprinted with permission. All rights reserved.) for moment diagrams that consist of straight lines between braced points:

$C_{b}=1.75+1.05\left(\frac{M_{1}}{M_{2}}\right)+0.3\left(\frac{M_{1}}{M_{2}}\right)^{2}$

where $M_{1}=$ the smaller moment at end of an unbraced length; $M_{2}=$ the larger moment at the end of an unbraced length; and $M_{1} / M_{2}=$ the absolute ratio of bending moment at the ends of the 
beam-column; the ratio is negative if bent in single curvature and positive if bent in reverse curvature.

\section{Design Example}

The typical floor plan for a three-story library building is shown in Fig. 5(a). Investigate the adequacy of the exterior columns in the ground floor of the moment frame shown in Fig. 5(b) located at the column line 3 shown in Fig. 5(a). Also, determine the magnitude of the frame sidesway due to partial-span floor live loading effects. The uniform roof and floor loads are given as follows: roof dead load $=60 \mathrm{psf}\left(2.87 \mathrm{kN} / \mathrm{m}^{2}\right)$, snow load $=35 \mathrm{psf}\left(1.68 \mathrm{kN} / \mathrm{m}^{2}\right)$, floor dead load $=90 \mathrm{psf}\left(4.31 \mathrm{kN} / \mathrm{m}^{2}\right)$, and the floor live load for library stack rooms containing shelves of books $=150 \mathrm{psf}\left(7.18 \mathrm{kN} / \mathrm{m}^{2}\right)$. Assume that the building is located in a region where the seismic loads do not control and the uniform lateral wind load (the sum of the design wind pressure on the windward wall and the design wind pressure on the leeward wall of the building) is $25 \mathrm{psf}\left(1.20 \mathrm{kN} / \mathrm{m}^{2}\right)$. The steel is A992 [ $\left.F_{y}=50 \mathrm{ksi}(345 \mathrm{MPa})\right]$. Use the Effective Length Method. For this example, consider only the following two load combinations (ASCE/SEI 2010): $1.2 \mathrm{D}+1.6 \mathrm{~L}+0.5 \mathrm{~S}$ and $1.2 \mathrm{D}+1.0 \mathrm{~W}+\mathrm{L}+0.5 \mathrm{~S}$.

Assume that the roof dead load $\left(\mathrm{D}_{\text {roof }}\right)$, snow load $(\mathrm{S})$, floor dead load $\left(\mathrm{D}_{\text {floor }}\right)$, and floor live load $\left(\mathrm{L}_{\text {floor }}\right)$ are all uniformly distributed along the beams in the moment frame in Fig. 5(b). Therefore, in Fig. 6(a), 1.2 $\mathrm{D}_{\text {roof }}+0.5 \mathrm{~S}=1.2(60 \mathrm{psf})(30 \mathrm{ft})+0.5(35 \mathrm{psf})(30 \mathrm{ft})=0.224 \mathrm{k} / \mathrm{in}(39.2$ $\mathrm{kN} / \mathrm{m})$ and $1.2 \mathrm{D}_{\text {floor }}=1.2(90 \mathrm{psf})(30 \mathrm{ft})=0.270 \mathrm{k} / \mathrm{in}(47.3 \mathrm{kN} / \mathrm{m})$. Also, in Fig. $7(\mathrm{a})$, the distributed wind loads on each level are $\mathrm{W}_{\text {roof }}=(25 \mathrm{psf})(6.5 \mathrm{ft})(30 \mathrm{ft})=4.875 \mathrm{kips}(21.7 \mathrm{kN})$ and $\mathrm{W}_{3 \mathrm{rd} \text { level }}=\mathrm{W}_{\text {2rd level }}=(25 \mathrm{psf})(13 \mathrm{ft})(30 \mathrm{ft})=9.75 \mathrm{kips}(43.4 \mathrm{kN})$. [Note that since the uniform lateral wind load is the sum of the design wind pressure on the windward wall and the design 
wind pressure on the leeward wall of the building, the resultant concentrated wind loads are applied to the interior column at each level as shown in Fig. 7(a)]. In addition, Fig. 7(a) also shows the frame deflection at each floor due to the applied wind loads. Furthermore, in Fig. 8, $\mathrm{L}_{\text {floor }}=(150 \mathrm{psf})(30 \mathrm{ft})=0.375 \mathrm{k} /$ in $(65.7 \mathrm{kN} / \mathrm{m})$. Using first-order elastic structural analyses (SAP2000 1997), the results of the axial forces and end moments of the exterior columns at column line $\mathrm{C}$ of the loaded frame in Fig. 6(a) are shown in Fig. 6(b), the results of that in Fig. 7(a) are shown in Fig. 7(b), and the results of that in Fig. 8 are shown in Fig. 9.

Six floor live load patterns that will possibly produce the maximum axial force and/or end moment for the exterior columns at column line $\mathrm{C}$ are shown in Fig. 8. Among the six load cases, three cases [Cases (A), (B), and (C)] are purely full-span loading conditions, while the other three [Cases (D), (E), and (F)] are combinations of partial-span and full-span loading conditions. The axial forces and end moments of the exterior columns at column line $\mathrm{C}$, shown in Fig. 9 (due to the floor live load cases shown in Fig. 8), indicate that the floor live load cases (B), (C), (D), and (F) may govern the design of the ground floor exterior column at column C. Therefore, the adequacy of the column for these four cases will be investigated. The notional load and the frame deflection due to the notional load for live load cases (B), (D), and (F) for the load combination 1.2D $+1.6 \mathrm{~L}+0.5 \mathrm{~S}$ are then computed and are shown in Figs. 10(a, b, and c) [Note that the notional load and the frame deflection are the same for live load cases (B) and (C)]. The adequacy of the column for the four critical cases is then investigated as follows:

(1) Floor Live Load Case (B) for the Loading Combination 1.2D + 1.6 $\mathrm{L}_{\text {case (B) }}+0.5 \mathrm{~S}$ :

$P_{n t}=126.3 \mathrm{k}($ from Fig. 6) $+1.6(61.6 \mathrm{k})[$ from Fig. $9(\mathrm{~b})]=224.9 \mathrm{k}(1000 \mathrm{kN})$ $M_{n t}=682 \mathrm{k"}$ (from Fig. 6) + 1.6(1238 k") [from Fig. 9(b)] = $2663 \mathrm{k"}(301 \mathrm{kN} \cdot \mathrm{m})$

Due to notional loads shown in Fig. 10(a), $P_{l t}=0.7 \mathrm{k}(3 \mathrm{kN})$, and $M_{l t}=77 \mathrm{k} "(9 \mathrm{kN} \cdot \mathrm{m})$. 
For the column W12×120 (AISC 2011), $I_{x}=1070 \mathrm{in}^{4}\left[4.45\left(10^{8}\right) \mathrm{mm}^{4}\right], b_{f} / 2 t_{f}=5.57, h / t_{w}=13.7$, $r_{x}=5.51^{\prime \prime}(140 \mathrm{~mm}), r_{y}=3.13^{\prime \prime}(80 \mathrm{~mm}), A=35.2 \mathrm{in}^{2}\left[2.27\left(10^{4}\right) \mathrm{mm}^{2}\right], L_{p}=11.1 \mathrm{ft}(3.38 \mathrm{~m}), L_{r}$ $=56.5 \mathrm{ft}(17.2 \mathrm{~m}), \phi_{b} B F=5.95 \mathrm{k}(26.5 \mathrm{kN})$, and $\phi_{b} M_{\mathrm{px}}=698 \mathrm{k}(946 \mathrm{kN} \cdot \mathrm{m})$.

From Eq. (7), $P_{e 1}=\frac{\pi^{2} E I}{\left(K_{1} L\right)^{2}}=\frac{\pi^{2}(29000)(1070)}{(1 \times 13 \times 12)^{2}}=12,584 \mathrm{k}(55974 \mathrm{kN})$.

From Eq. (6), $C_{m}=0.6-0.4\left(M_{1} / M_{2}\right)=0.6-0.4(-0 / 2663)=0.6$.

From Eq. (5), $B_{1}=\frac{C_{m}}{1-\frac{\alpha P_{r}}{P_{e 1}}}=\frac{0.6}{1-\frac{(1.0)(224.9+0.7)}{12584}}=0.611<1.0$

Since $B_{1}<1.0$, use $B_{1}=1.0$.

From Figs. 6(a) and 8(b),

$P_{\text {story }}=0.224 \mathrm{k} /$ in $\times 60 \times 12^{\prime \prime}+0.270 \mathrm{k} /$ in $\times 2 \times 60 \times 12^{\prime \prime}+1.6 \times 0.375 \mathrm{k} /$ in $\times 2 \times 30 \times 12$ " $=982 \mathrm{k}(4368 \mathrm{kN})$.

From Eq. (10), $R_{M}=1-0.15\left(P_{m f} / P_{\text {story }}\right)=1-0.15(982 / 982)=0.85$.

From Eq. (9) and Fig. 10(a),

$P_{e^{\text {story }}}=R_{M}\left(\frac{H L}{\Delta_{H}}\right)=0.85\left[\frac{(0.32 \mathrm{k}+0.82 \mathrm{k}+0.82 \mathrm{k})\left(13 \times 12^{\prime \prime}\right)}{0.0303^{\prime \prime}}\right]=8577 \mathrm{k}(38150 \mathrm{kN})$.

Using Eq. (8), $B_{2}=\frac{1}{1-\frac{\alpha P_{\text {story }}}{P_{\text {e story }}}}=\frac{1}{1-\frac{(1.0)(982 \mathrm{k})}{8577 \mathrm{k}}}=1.13$.

Using Eq. (3), $P_{r}=P_{n t}+B_{2} P_{l t}=224.9 \mathrm{k}+1.13(0.7 \mathrm{k})=225.7 \mathrm{k}(1004 \mathrm{kN})$.

Using Eq. (4), $M_{r x}=B_{1} M_{n t}+B_{2} M_{l t}=1.0(2663 \mathrm{k} ")+1.13(77 \mathrm{k} ")=2750 \mathrm{k} "(311 \mathrm{kN} \cdot \mathrm{m})$.

Assuming that there is no bending moment about the y-axis of the column, one has $M_{r y}=0$. 
Since $b_{f} / 2 t_{f}=5.57<0.56 \sqrt{E / F_{y}}=13.49$ and $h / t_{w}=13.7<1.49 \sqrt{E / F_{y}}=35.88$, the W $12 \times 120$ column is a non-slender compression member.

From Eq. (17), $G_{\text {top }}=\frac{\sum\left(\frac{I}{L}\right)_{\text {columns }}}{\sum\left(\frac{I}{L}\right)_{\text {beams }}}=\frac{2\left(\frac{1070}{13}\right)}{\frac{3270}{30}}=1.51$.

Note that $I_{x}=3270 \mathrm{in}^{4}\left[1.36\left(10^{9}\right) \mathrm{mm}^{4}\right]$ for the W27 $\times 94$ beam (AISC 2011).

Also, $G_{b o t}=10$ for practical designs for column bases supported by, but not rigidly connected to, a footing or foundation.

Using Eq. (16),

$K_{x}=\sqrt{\frac{1.6 G_{t o p} G_{b o t}+4.0\left(G_{t o p}+G_{b o t}\right)+7.5}{\left(G_{\text {top }}+G_{b o t}\right)+7.5}}=\sqrt{\frac{1.6(1.51)(10)+4.0(1.51+10)+7.5}{(1.51+10)+7.5}}=2.02$.

Also, referring to Fig. 5(a), since there is no leaning column in the direction of translation being considered, $\Sigma P_{\text {leaning }}=0$.

Using Eq. (18), $\mathrm{K}_{\mathrm{m}}=\left(\sqrt{1+\frac{\sum P_{\text {leaning }}}{\sum P_{\text {stability }}}}\right) K_{x}=K_{x}=2.02$.

Thus, $\frac{K_{x} L_{x}}{r_{x}}=\frac{2.02(13 \times 12)}{5.51}=57.2$.

Furthermore, since the column's y-axis is considered braced at the column's ends, $K_{y}=1.0$.

Thus, $\frac{K_{y} L_{y}}{r_{y}}=\frac{(1.0)(13 \times 12)}{3.13}=49.8$.

Since $\frac{K_{y} L_{y}}{r_{y}}<\frac{K_{x} L_{x}}{r_{x}}, \frac{K_{x} L_{x}}{r_{x}}$ governs. 
From Eq. (15), $F_{e}=\frac{\pi^{2} E}{\left(\frac{K L}{r}\right)^{2}}=\frac{\pi^{2}(29000)}{(57.2)^{2}}=87.48 \mathrm{ksi}(603 \mathrm{MPa})$.

Since $\frac{F_{y}}{F_{e}}=\frac{50}{87.48}=0.572 \leq 2.25$,

$F_{c r}=\left[0.658^{\frac{F_{y}}{F_{e}}}\right] F_{y}=\left(0.658^{0.572}\right)(50)=39.36 \mathrm{ksi}(271 \mathrm{MPa})$.

Using Eq. (12), $P_{c}=\phi_{c} F_{c r} A_{g}=0.9(39.36)(35.2)=1247 \mathrm{k}(5547 \mathrm{kN})$.

Since $b_{f} / 2 t_{f}=5.57<0.38 \sqrt{E / F_{y}}=9.15$ and $h / t_{w}=13.7<3.76 \sqrt{E / F_{y}}=90.6$, the $\mathrm{W} 12 \times 120$ column is a compact compression member.

From Eq. (22), $C_{b}=1.75+1.05\left(\frac{M_{1}}{M_{2}}\right)+0.3\left(\frac{M_{1}}{M_{2}}\right)^{2}=1.75$ (Since $M_{1}=0$ at the base of the column).

Also, since $L_{p}=11.1 \mathrm{ft}(3.38 \mathrm{~m})<L_{b}=13.0 \mathrm{ft}(3.96 \mathrm{~m})<L_{r}=56.5 \mathrm{ft}(17.2 \mathrm{~m})$, use Eq. (20) to compute $M_{c x}$ :

$$
\begin{aligned}
M_{c x} & =C_{b}\left[\phi_{b} M_{p x}-\phi_{b} B F\left(L_{b}-L_{p}\right)\right]=1.75[698-5.95(13-11.1)]=1202 \mathrm{k}^{\prime}(1630 \mathrm{kN} \cdot \mathrm{m}) \\
& >\phi_{b} M_{\mathrm{px}}=698 \mathrm{k}^{\prime}(946 \mathrm{kN} \cdot \mathrm{m}) .
\end{aligned}
$$

Thus, $M_{c x}=\phi_{b} M_{p x}=698 \mathrm{k}^{\prime}(946 \mathrm{kN} \cdot \mathrm{m})$.

Since $\frac{P_{r}}{P_{c}}=\frac{225.7}{1247}=0.181<0.2$, use Eq. (2) to investigate the adequacy of the column:

$$
\frac{P_{r}}{2 P_{c}}+\left(\frac{M_{r x}}{M_{c x}}+\frac{M_{r y}}{M_{c y}}\right)=\frac{0.181}{2}+\left(\frac{2750}{698 \times 12}+0\right)=0.419<1.0 \quad \text { OK }
$$

Thus, the column is adequate due to the loading combination $1.2 \mathrm{D}+1.6 \mathrm{~L}_{\text {case }(\mathrm{B})}+0.5 \mathrm{~S}$. 
(2) Floor Live Load Case (B) for the Loading Combination 1.2D + 1.0W $+\mathrm{L}_{\text {case (B) }}+0.5 \mathrm{~S}$ :

$P_{n t}=126.3 \mathrm{k}($ from Fig. 6) $+61.6 \mathrm{k}[$ from Fig. $9(\mathrm{~b})]=187.9 \mathrm{k}(836 \mathrm{kN})$

$M_{n t}=682$ k" (from Fig. 6) + 1238 k" [from Fig. 9(b)] = 1920 k" (217 kN·m)

Due to wind loads shown in Fig. $7, P_{l t}=9.5 \mathrm{k}(42 \mathrm{kN})$, and $M_{l t}=950 \mathrm{k} "(107 \mathrm{kN} \cdot \mathrm{m})$.

Referring to the computation carried out in the loading combination $1.2 \mathrm{D}+1.6 \mathrm{~L}_{\text {case (B) }}+0.5 \mathrm{~S}$, one has $P_{e 1}=12,584 \mathrm{k}(55974 \mathrm{kN}), P_{c}=1247 \mathrm{k}(5547 \mathrm{kN})$, and $M_{c x}=698 \mathrm{k}^{\prime}(946 \mathrm{kN} \cdot \mathrm{m})$.

From Eq. (6), $C_{m}=0.6-0.4\left(M_{1} / M_{2}\right)=0.6-0.4(-0 / 1920)=0.6$.

From Eq. (5), $B_{1}=\frac{C_{m}}{1-\frac{\alpha P_{r}}{P_{e 1}}}=\frac{0.6}{1-\frac{(1.0)(187.9+9.5)}{12584}}=0.610<1.0$

Since $B_{1}<1.0$, use $B_{1}=1.0$.

From Figs. 6(a) and 8(b),

$P_{\text {story }}=0.224 \mathrm{k} /$ in $\times 60 \times 12^{\prime \prime}+0.270 \mathrm{k} /$ in $\times 2 \times 60 \times 12^{\prime \prime}+0.375 \mathrm{k} / \mathrm{in} \times 2 \times 30 \times 12^{\prime \prime}$ $=820 \mathrm{k}(3648 \mathrm{kN})$.

From Eq. (10), $R_{M}=1-0.15\left(P_{m f} / P_{\text {story }}\right)=1-0.15(820 / 820)=0.85$.

From Eq. (9) and Fig. 7(a),

$P_{\text {e story }}=R_{M}\left(\frac{H L}{\Delta_{H}}\right)=0.85\left[\frac{(4.875 \mathrm{k}+9.75 \mathrm{k}+9.75 \mathrm{k})\left(13 \times 12^{\prime \prime}\right)}{0.3788^{\prime \prime}}\right]=8533 \mathrm{k}(37955 \mathrm{kN})$.

Using Eq. (8), $B_{2}=\frac{1}{1-\frac{\alpha P_{\text {story }}}{P_{e \text { story }}}}=\frac{1}{1-\frac{(1.0)(820 \mathrm{k})}{8533 \mathrm{k}}}=1.11$

Using Eq. (3), $P_{r}=P_{n t}+B_{2} P_{l t}=187.9 \mathrm{k}+1.11(9.5 \mathrm{k})=198.4 \mathrm{k}(882 \mathrm{kN})$.

Using Eq. (4), $M_{r x}=B_{1} M_{n t}+B_{2} M_{l t}=1.0\left(1920 \mathrm{k}^{\prime \prime}\right)+1.11\left(950 \mathrm{k}^{\prime \prime}\right)=2975 \mathrm{k} "(336 \mathrm{kN} \cdot \mathrm{m})$.

Since $\frac{P_{r}}{P_{c}}=\frac{198.4}{1247}=0.159<0.2$, use Eq. (2) to investigate the adequacy of the column: 
$\frac{P_{r}}{2 P_{c}}+\left(\frac{M_{r x}}{M_{c x}}+\frac{M_{r y}}{M_{c y}}\right)=\frac{0.159}{2}+\left(\frac{2975}{698 \times 12}+0\right)=0.435<1.0 \quad$ OK

Thus, the column is adequate due to the loading combination $1.2 \mathrm{D}+1.0 \mathrm{~W}+\mathrm{L}_{\text {case (B) }}+0.5 \mathrm{~S}$.

(3) Floor Live Load Case (C) for the Loading Combination 1.2D + 1.6 $\mathrm{L}_{\text {case (C) }}+0.5 \mathrm{~S}$ :

Following the computation procedure carried out in the loading combination $1.2 \mathrm{D}+1.6 \mathrm{~L}_{\text {case (B) }}+$ $0.5 \mathrm{~S}$, one has $P_{r}=333.7 \mathrm{k}(1484 \mathrm{kN}), M_{r x}=2407 \mathrm{k} "(272 \mathrm{kN} \cdot \mathrm{m}), P_{c}=1247 \mathrm{k}(5547 \mathrm{kN})$, and $M_{c x}=698 \mathrm{k}^{\prime}(946 \mathrm{kN} \cdot \mathrm{m})$.

Since $\frac{P_{r}}{P_{c}}=\frac{333.7}{1247}=0.268>0.2$, use Eq. (1) to investigate the adequacy of the column: $\frac{P_{r}}{P_{c}}+\frac{8}{9}\left(\frac{M_{r x}}{M_{c x}}+\frac{M_{r y}}{M_{c y}}\right)=0.268+\frac{8}{9}\left(\frac{2407}{698 \times 12}+0\right)=0.523<1.0 \quad$ OK

Thus, the column is adequate due to the loading combination $1.2 \mathrm{D}+1.6 \mathrm{~L}_{\text {case }(\mathrm{C})}+0.5 \mathrm{~S}$.

(4) Floor Live Load Case (C) for the Loading Combination 1.2D $+1.0 \mathrm{~W}+\mathrm{L}_{\text {case (C) }}+0.5 \mathrm{~S}$ :

Following the computation procedure carried out in the loading combination $1.2 \mathrm{D}+1.0 \mathrm{~W}+$ $\mathrm{L}_{\text {case(B) }}+0.5 \mathrm{~S}$, one has $P_{r}=265.9 \mathrm{k}(1183 \mathrm{kN}), M_{r x}=2761 \mathrm{k} "(312 \mathrm{kN} \cdot \mathrm{m}), P_{c}=1247 \mathrm{k}(5547$ $\mathrm{kN})$, and $M_{c x}=698 \mathrm{k}^{\prime}(946 \mathrm{kN} \cdot \mathrm{m})$.

Since $\frac{P_{r}}{P_{c}}=\frac{265.9}{1247}=0.213>0.2$, use Eq. (1) to investigate the adequacy of the column: $\frac{P_{r}}{P_{c}}+\frac{8}{9}\left(\frac{M_{r x}}{M_{c x}}+\frac{M_{r y}}{M_{c y}}\right)=0.213+\frac{8}{9}\left(\frac{2761}{698 \times 12}+0\right)=0.506<1.0 \quad$ OK

Thus, the column is adequate due to the loading combination $1.2 \mathrm{D}+1.0 \mathrm{~W}+\mathrm{L}_{\text {case }(\mathrm{C})}+0.5 \mathrm{~S}$.

(5) Floor Live Load Case (D) for the Loading Combination 1.2D + 1.6 $\mathrm{L}_{\text {case (D) }}+0.5 \mathrm{~S}$ : $P_{n t}=126.3 \mathrm{k}($ from Fig. 6) + 1.6(126.8 k) [from Fig. 11(b)] $=329.2 \mathrm{k}(1464 \mathrm{kN})$ $M_{n t}=682 \mathrm{k"}($ from Fig. 6) + 1.6(953 k") [from Fig. 11(b)] = 2207 k" $(249 \mathrm{kN} \cdot \mathrm{m})$ 
Due to notional loads [Fig. 10(b)] and sway forces [Fig. 11(c)], $P_{l t}=0.9 \mathrm{k}+1.6(2 \mathrm{k})=4.1 \mathrm{k}(18$ $\mathrm{kN})$, and $M_{l t}=94 \mathrm{k}^{\prime \prime}+1.6\left(101 \mathrm{~K}^{\prime \prime}\right)=256 \mathrm{~K} "(29 \mathrm{kN} \cdot \mathrm{m})$.

Referring to the computation carried out in the loading combination $1.2 \mathrm{D}+1.6 \mathrm{~L}_{\text {case (B) }}+0.5 \mathrm{~S}$, one has $P_{e 1}=12,584 \mathrm{k}(55974 \mathrm{kN}), P_{c}=1247 \mathrm{k}(5547 \mathrm{kN})$, and $M_{c x}=698 \mathrm{k}^{\prime}(946 \mathrm{kN} \cdot \mathrm{m})$.

From Eq. (6), $C_{m}=0.6-0.4\left(M_{1} / M_{2}\right)=0.6-0.4(-0 / 2207)=0.6$.

From Eq. (5), $B_{1}=\frac{C_{m}}{1-\frac{\alpha P_{r}}{P_{e 1}}}=\frac{0.6}{1-\frac{(1.0)(329.2+4.1)}{12584}}=0.616<1.0$

Since $B_{1}<1.0$, use $B_{1}=1.0$.

From Figs. 6(a) and 8(d),

$P_{\text {story }}=0.224 \mathrm{k} /$ in $\times 60 \times 12^{\prime \prime}+0.270 \mathrm{k} /$ in $\times 2 \times 60 \times 12^{\prime \prime}+1.6 \times 0.375 \mathrm{k} / \mathrm{in} \times 3 \times 30 \times 12^{\prime \prime}$ $=1198 \mathrm{k}(5329 \mathrm{kN})$.

From Eq. (10), $R_{M}=1-0.15\left(P_{m f} / P_{\text {story }}\right)=1-0.15(1198 / 1198)=0.85$.

From Eq. (9) and Figs. 10(b) and 11(c),

$$
\begin{aligned}
P_{\text {e story }} & =R_{M}\left(\frac{H L}{\Delta_{H}}\right)=0.85\left[\frac{[(0.32 \mathrm{k}+1.04 \mathrm{k}+1.04 \mathrm{k})+1.6(2.93 \mathrm{k}+0.35 \mathrm{k}-0.67 \mathrm{k})]\left(13 \times 12^{\prime \prime}\right)}{0.0370^{\prime \prime}+1.6\left(0.0447^{\prime \prime}\right)}\right] \\
& =8035 \mathrm{k}(35740 \mathrm{kN}) .
\end{aligned}
$$

Using Eq. (8), $B_{2}=\frac{1}{1-\frac{\alpha P_{\text {story }}}{P_{\text {e story }}}}=\frac{1}{1-\frac{(1.0)(1198 \mathrm{k})}{8035 \mathrm{k}}}=1.18$.

Using Eq. (3), $P_{r}=P_{n t}+B_{2} P_{l t}=329.2 \mathrm{k}+1.18(4.1 \mathrm{k})=334.0 \mathrm{k}(1486 \mathrm{kN})$.

Using Eq. (4), $M_{r x}=B_{1} M_{n t}+B_{2} M_{l t}=1.0\left(2207 \mathrm{k}^{\prime \prime}\right)+1.18(256 \mathrm{k} ")=2509 \mathrm{k} "(283 \mathrm{kN} \cdot \mathrm{m})$.

Since $\frac{P_{r}}{P_{c}}=\frac{334.0}{1247}=0.268>0.2$, use Eq. (1) to investigate the adequacy of the column: 
$\frac{P_{r}}{P_{c}}+\frac{8}{9}\left(\frac{M_{r x}}{M_{c x}}+\frac{M_{r y}}{M_{c y}}\right)=0.268+\frac{8}{9}\left(\frac{2509}{698 \times 12}+0\right)=0.534<1.0 \quad$ OK

Thus, the column is adequate due to the loading combination $1.2 \mathrm{D}+1.6 \mathrm{~L}_{\text {case (D) }}+0.5 \mathrm{~S}$.

(6) Floor Live Load Case (D) for the Loading Combination 1.2D + 1.0W $+\mathrm{L}_{\text {case (D) }}+0.5 \mathrm{~S}$ :

$P_{n t}=126.3 \mathrm{k}($ from Fig. 6) $+126.8 \mathrm{k}$ [from Fig. $11(\mathrm{~b})]=253.1 \mathrm{k}(1126 \mathrm{kN})$

$M_{n t}=682$ k" (from Fig. 6) + 953 k" [from Fig. 11(b)] = 1635 k" (185 kN·m)

Due to sway forces [Fig. 11(c)] and wind loads (Fig. 7), $P_{l t}=2 \mathrm{k}+9.5 \mathrm{k}=11.5 \mathrm{k}(51 \mathrm{kN})$, and $M_{l t}=101 \mathrm{k}^{\prime \prime}+950 \mathrm{~K} "=1051^{\prime \prime}(119 \mathrm{kN} \cdot \mathrm{m})$.

Referring to the computation carried out in the loading combination $1.2 \mathrm{D}+1.6 \mathrm{~L}_{\text {case (B) }}+0.5 \mathrm{~S}$, one has $P_{e 1}=12,584 \mathrm{k}(55974 \mathrm{kN}), P_{c}=1247 \mathrm{k}(5547 \mathrm{kN})$, and $M_{c x}=698 \mathrm{k}(946 \mathrm{kN} \cdot \mathrm{m})$.

From Eq. (6), $C_{m}=0.6-0.4\left(M_{1} / M_{2}\right)=0.6-0.4(-0 / 1635)=0.6$.

From Eq. (5), $B_{1}=\frac{C_{m}}{1-\frac{\alpha P_{r}}{P_{e 1}}}=\frac{0.6}{1-\frac{(1.0)(253.1+11.5)}{12584}}=0.613<1.0$

Since $B_{1}<1.0$, use $B_{1}=1.0$.

From Figs. 6(a) and 8(d),

$P_{\text {story }}=0.224 \mathrm{k} / \mathrm{in} \times 60 \times 12^{\prime \prime}+0.270 \mathrm{k} / \mathrm{in} \times 2 \times 60 \times 12^{\prime \prime}+0.375 \mathrm{k} / \mathrm{in} \times 3 \times 30 \times 12^{\prime \prime}$ $=955.1 \mathrm{k}(4248 \mathrm{kN})$.

From Eq. (10), $R_{M}=1-0.15\left(P_{m f} / P_{\text {story }}\right)=1-0.15(955.1 / 955.1)=0.85$.

From Eq. (9) and Figs. 11(c) and 7(a),

$$
\begin{aligned}
P_{e \text { story }} & =R_{M}\left(\frac{H L}{\Delta_{H}}\right)=0.85\left[\frac{[(2.93 \mathrm{k}+0.35 \mathrm{k}-0.67 \mathrm{k})+(4.875 \mathrm{k}+9.75 \mathrm{k}+9.75 \mathrm{k})]\left(13 \times 12^{\prime \prime}\right)}{0.0447^{\prime \prime}+0.3788^{\prime \prime}}\right] \\
& =8449 \mathrm{k}(37581 \mathrm{kN}) .
\end{aligned}
$$


Using Eq. (8), $B_{2}=\frac{1}{1-\frac{\alpha P_{\text {story }}}{P_{\text {e story }}}}=\frac{1}{1-\frac{(1.0)(955.1 \mathrm{k})}{8449 \mathrm{k}}}=1.13$.

Using Eq. (3), $P_{r}=P_{n t}+B_{2} P_{l t}=253.1 \mathrm{k}+1.13(11.5 \mathrm{k})=266.1 \mathrm{k}(1184 \mathrm{kN})$.

Using Eq. (4), $M_{r x}=B_{1} M_{n t}+B_{2} M_{l t}=1.0(1635 \mathrm{k} ")+1.13(1051 \mathrm{k} ")=2823 \mathrm{k} "(319 \mathrm{kN} \cdot \mathrm{m})$.

Since $\frac{P_{r}}{P_{c}}=\frac{266.1}{1247}=0.213>0.2$, use Eq. (1) to investigate the adequacy of the column:

$\frac{P_{r}}{P_{c}}+\frac{8}{9}\left(\frac{M_{r x}}{M_{c x}}+\frac{M_{r y}}{M_{c y}}\right)=0.268+\frac{8}{9}\left(\frac{2823}{698 \times 12}+0\right)=0.513<1.0 \quad$ OK

Thus, the column is adequate due to the loading combination $1.2 \mathrm{D}+1.0 \mathrm{~W}+\mathrm{L}_{\text {case (D) }}+0.5 \mathrm{~S}$.

(7) Floor Live Load Case (F) for the Loading Combination 1.2D + 1.6 $\mathrm{L}_{\text {case }(\mathrm{F})}+0.5 \mathrm{~S}$ :

Following the computation procedure carried out in the loading combination $1.2 \mathrm{D}+1.6 \mathrm{~L}_{\text {case (D) }}{ }^{+}$ $0.5 \mathrm{~S}$ and using Figs. 10(c) and 12, one has $P_{r}=330.0 \mathrm{k}(1468 \mathrm{kN}), M_{r x}=2577 \mathrm{k} "(291 \mathrm{kN} \cdot \mathrm{m})$, $P_{c}=1247 \mathrm{k}(5547 \mathrm{kN})$, and $M_{c x}=698 \mathrm{k}(946 \mathrm{kN} \cdot \mathrm{m})$.

Since $\frac{P_{r}}{P_{c}}=\frac{330.0}{1247}=0.265>0.2$, use Eq. (1) to investigate the adequacy of the column:

$\frac{P_{r}}{P_{c}}+\frac{8}{9}\left(\frac{M_{r x}}{M_{c x}}+\frac{M_{r y}}{M_{c y}}\right)=0.265+\frac{8}{9}\left(\frac{2577}{698 \times 12}+0\right)=0.538<1.0 \quad$ OK

Thus, the column is adequate due to the loading combination $1.2 \mathrm{D}+1.6 \mathrm{~L}_{\text {case (F) }}+0.5 \mathrm{~S}$.

(8) Floor Live Load Case (F) for the Loading Combination 1.2D $+1.0 \mathrm{~W}+\mathrm{L}_{\text {case (F) }}+0.5 \mathrm{~S}$ :

Following the computation procedure carried out in the loading combination $1.2 \mathrm{D}+1.0 \mathrm{~W}+$ $\mathrm{L}_{\text {case(D) }}+0.5 \mathrm{~S}$ and using Fig. 12 , one has $P_{r}=263.3 \mathrm{k}(1171 \mathrm{kN}), M_{r x}=2871 \mathrm{k} "(324 \mathrm{kN} \cdot \mathrm{m}), P_{c}$ $=1247 \mathrm{k}(5547 \mathrm{kN})$, and $M_{c x}=698 \mathrm{k}^{\prime}(946 \mathrm{kN} \cdot \mathrm{m})$.

Since $\frac{P_{r}}{P_{c}}=\frac{263.3}{1247}=0.211>0.2$, use Eq. (1) to investigate the adequacy of the column: 


$$
\frac{P_{r}}{P_{c}}+\frac{8}{9}\left(\frac{M_{r x}}{M_{c x}}+\frac{M_{r y}}{M_{c y}}\right)=0.211+\frac{8}{9}\left(\frac{2871}{698 \times 12}+0\right)=0.516<1.0 \quad \text { OK }
$$

Thus, the column is adequate due to the loading combination $1.2 \mathrm{D}+1.0 \mathrm{~W}+\mathrm{L}_{\text {case }(\mathrm{F})}+0.5 \mathrm{~S}$.

A summary of the required strength to the design strength ratios of the ground floor column located at the intersection of column lines 3 and $\mathrm{C}$ (shown in Fig. 5) for various floor live load cases are shown in Table 1.

The story drifts due to various floor live load patterns have been computed. The results indicate that the story drifts of the frame caused by full-span load patterns [the floor live load cases (A), (B), and (C) shown in Fig. 8] are small enough and thus, an assumption can be made that there is no lateral translation of the frame. However, as shown in Figs. 11 and 12, the sidesway of the frame become more evident when there are more spans with a partial-span live loading. Fig. 13 shows the magnitude of the sidesway for each floor when all the floor spans are all partially loaded on the same side of the span.

Table 2 summarizes and compares the magnitude of the sidesway for the frame due to the partial-span floor live loads, as shown in Fig. 13, and the wind loads, as shown in Fig. 7. Table 3 summarizes and compares the magnitude of the story drift for the frame due to the partial-span floor live loads, as shown in Fig. 13, and the wind loads, as shown in Fig. 7.

\section{Conclusion}

For the design of a structural member in a moment frame, the live load pattern must be varied to determine the maximum axial force and/or bending moment in the structural member. The live load pattern that produces the maximum axial force and/or bending moment in the structural member under consideration is the critical live load pattern. Structural engineers commonly select the critical live load pattern from various full-span live load patterns rather than partial- 
span live load patterns. However, the results of the study conducted in this paper indicate that: (1) the maximum required strength to design strength ratios of the exterior column of a frame that is subjected to a particular partial-span live load case is higher than that of a frame that is subjected to various full-span live load cases; (2) the story drifts and the horizontal displacement of an entire frame due to a particular partial-span live load case could be very significant (especially when the live load to dead load ratio is high); and (3) the partial-span loading effects on the deflection of an entire frame are more significant if there are more partial-span loaded bays in the same story. Thus, for the design of a multi-story multi-bay moment frame with a high live load to dead load ratio, the effects caused by partial-span live load patterns could be more critical than those caused by full-span live load patterns, not only in the computation of the required strength of the structural members, but also in the calculation of the story drifts and the lateral displacement of the entire frame.

\section{References}

AISC. (2006). Seismic design manual, American Institute of Steel Construction, Chicago, IL.

AISC. (2010). Specification for structural steel buildings, ANSI/AISC 360-10, American Institute of Steel Construction, Chicago, IL.

AISC. (2011). Steel construction manual, $14^{\text {th }}$ Ed., American Institute of Steel Construction, Chicago, IL.

ASCE/SEI. (2010). Minimum design loads for buildings and other structures, ASCE/SEI 7-10, ASCE, Reston, VA.

Dumonteil, P. (1992). "Simple equations for effective length factors." Engineering Journal, AISC, $3^{\text {rd }}$ Quarter, pp.111-115.

Leet, R.M., and Uang, C. (2002). Fundamentals of Structural Analysis, McGraw-Hill Companies, Inc., New York.

SAP2000 Educational. (1997). SAP2000 manuals, Computers and Structures, Inc., Berkeley, CA. 
Vinnakota, S. (2006). Steel structures: behavior and LRFD, McGraw-Hill Companies, Inc., New York. 
Table 1. Required Strength to Design Strength Ratios of the Ground Floor Column Located at the Intersection of Column lines 3 and $\mathrm{C}$ for Various Floor Live Load Cases

\begin{tabular}{lcclc}
\hline Load combinations & $\begin{array}{l}\text { Live load } \\
\text { case (B) } \\
\text { (A full-span live } \\
\text { load case) }\end{array}$ & $\begin{array}{l}\text { Live load } \\
\text { case (C) } \\
\text { (A full-span live } \\
\text { load case) }\end{array}$ & $\begin{array}{l}\text { Live load } \\
\text { case (D) } \\
\text { (A partial-span live } \\
\text { load case) }\end{array}$ & $\begin{array}{l}\text { Live load } \\
\text { case (F) } \\
\text { (A partial-span live } \\
\text { load case) }\end{array}$ \\
\hline $1.2 \mathrm{D}+1.6 \mathrm{~L}+0.5 \mathrm{~S}$ & 0.419 & 0.523 & 0.534 & 0.538 \\
$1.2 \mathrm{D}+1.0 \mathrm{~W}+\mathrm{L}+0.5 \mathrm{~S}$ & 0.435 & 0.506 & 0.513 & 0.516 \\
\hline
\end{tabular}

Table 2. Comparison of the Magnitude of the Sidesway for the Frame Due to the Partial-Span Floor Live Load, as Shown in Fig. 13, and the Wind Loads, as Shown in Fig. 7

\begin{tabular}{|c|c|c|c|}
\hline Applied loads & $\begin{array}{l}\text { Horizontal displacement } \\
\text { at the roof level }\left(\Delta_{R}\right)\end{array}$ & $\begin{array}{l}\text { Horizontal displacement } \\
\text { at the } 3^{\text {rd }} \text { floor level }\left(\Delta_{3}\right)\end{array}$ & $\begin{array}{l}\text { Horizontal displacement } \\
\text { at the } 2^{\text {nd }} \text { floor level }\left(\Delta_{2}\right)\end{array}$ \\
\hline Partial-span live loads & $0.1800 "(4.57 \mathrm{~mm})$ & $0.1406 "(3.57 \mathrm{~mm})$ & $0.0719 "(1.83 \mathrm{~mm})$ \\
\hline Wind loads & $0.5592 "(14.20 \mathrm{~mm})$ & $0.5058 "(12.85 \mathrm{~mm})$ & $0.3788 "(9.62 \mathrm{~mm})$ \\
\hline
\end{tabular}

Table 3. Comparison of the Magnitude of the Story Drift for the Frame Due to the Partial-Span Floor Live Load, as Shown in Fig. 13, and the Wind Loads, as Shown in Fig. 7

\begin{tabular}{|c|c|c|c|}
\hline Applied loads & $\begin{array}{l}\text { Story drift between roof } \\
\text { and } 3^{\text {rd }} \text { level }\left(\Delta_{R}-\Delta_{3}\right)\end{array}$ & $\begin{array}{l}\text { Story drift between } 3^{\text {rd }} \\
\text { and } 2^{\text {nd }} \text { levels }\left(\Delta_{3}-\Delta_{2}\right)\end{array}$ & $\begin{array}{l}\text { Story drift between } 2^{\text {nd }} \\
\text { and ground levels }\left(\Delta_{2}\right)\end{array}$ \\
\hline Partial-span live loads & 0.0394" (1.00 mm) & $0.0687 "(1.74 \mathrm{~mm})$ & $0.0719 "(1.83 \mathrm{~mm})$ \\
\hline Wind loads & $0.0534 "(1.36 \mathrm{~mm})$ & $0.1270 "(3.23 \mathrm{~mm})$ & $0.3788 "(9.62 \mathrm{~mm})$ \\
\hline
\end{tabular}




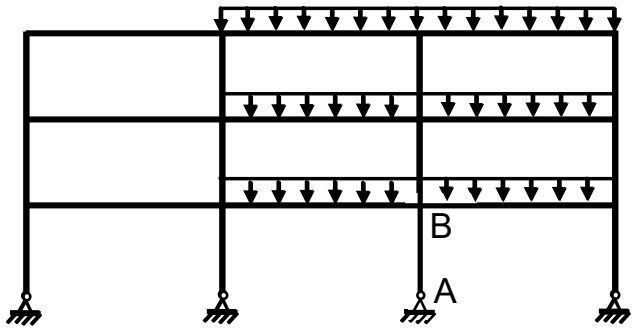

(a)

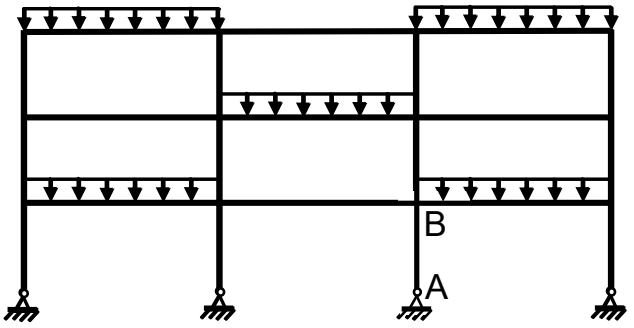

(b)

Fig. 1. Live load patterns to maximize the axial Force or end moment in columns 


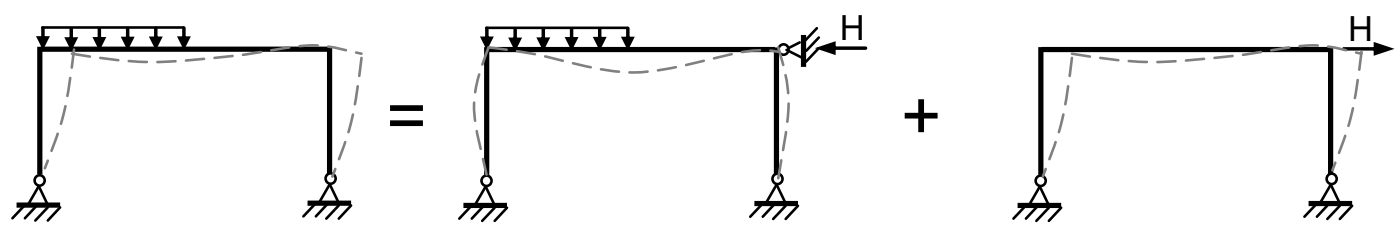

(a)

(b)

(c)

Fig. 2. Sway force due to a partial-span live load 


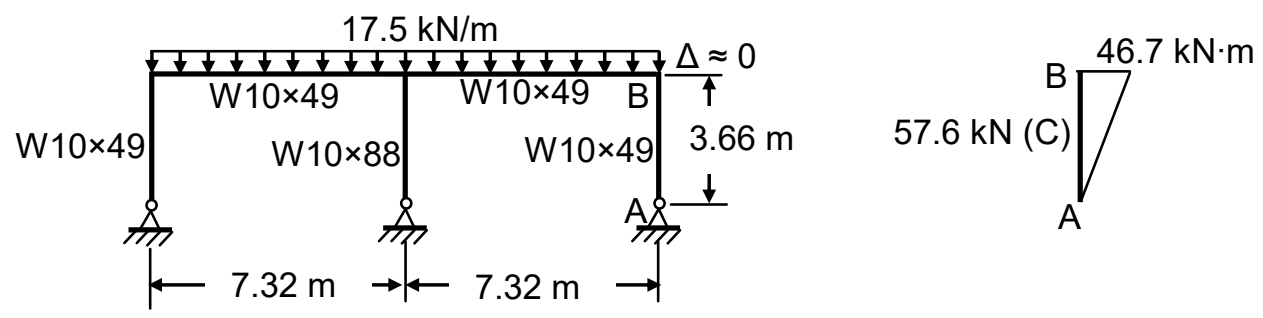

(a)

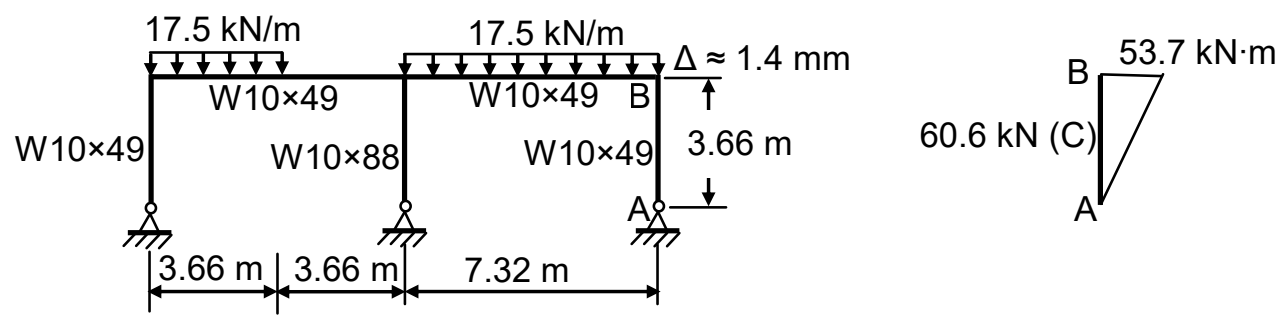

(b)

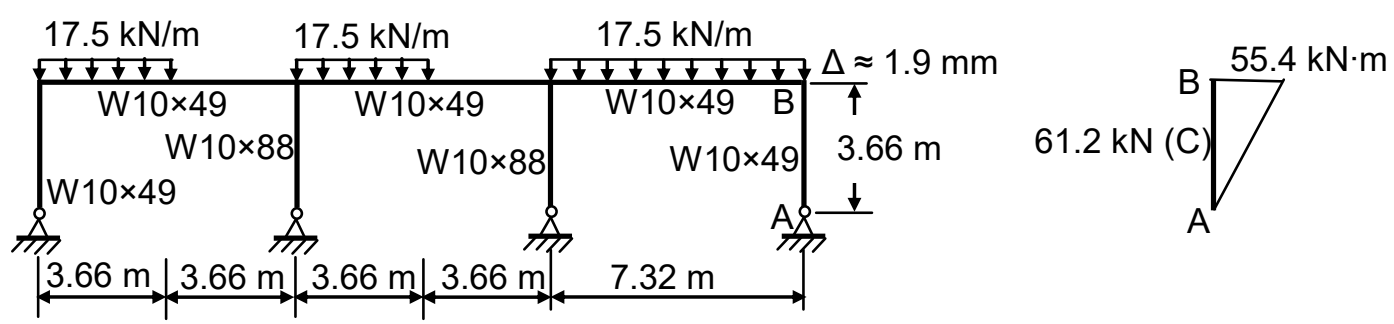

(c)

Fig. 3. Partial-span live loading effects on the sidesway of frames and the axial forces and end moments of exterior columns 


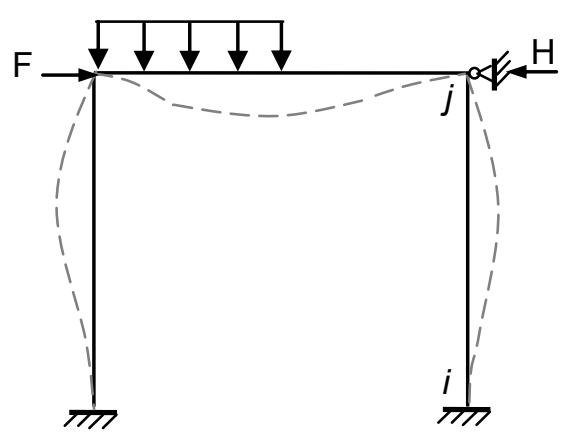

(a) No lateral translation of the frame (first-order analysis)

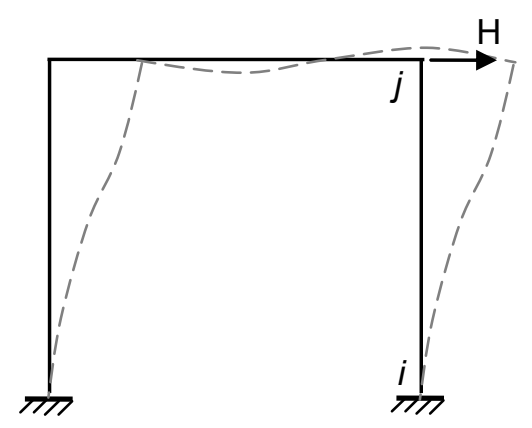

(b) Lateral translation of the frame (first-order analysis)
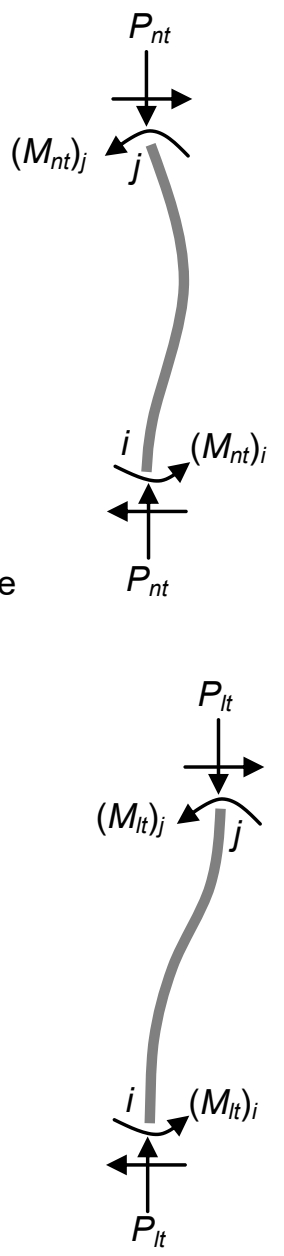

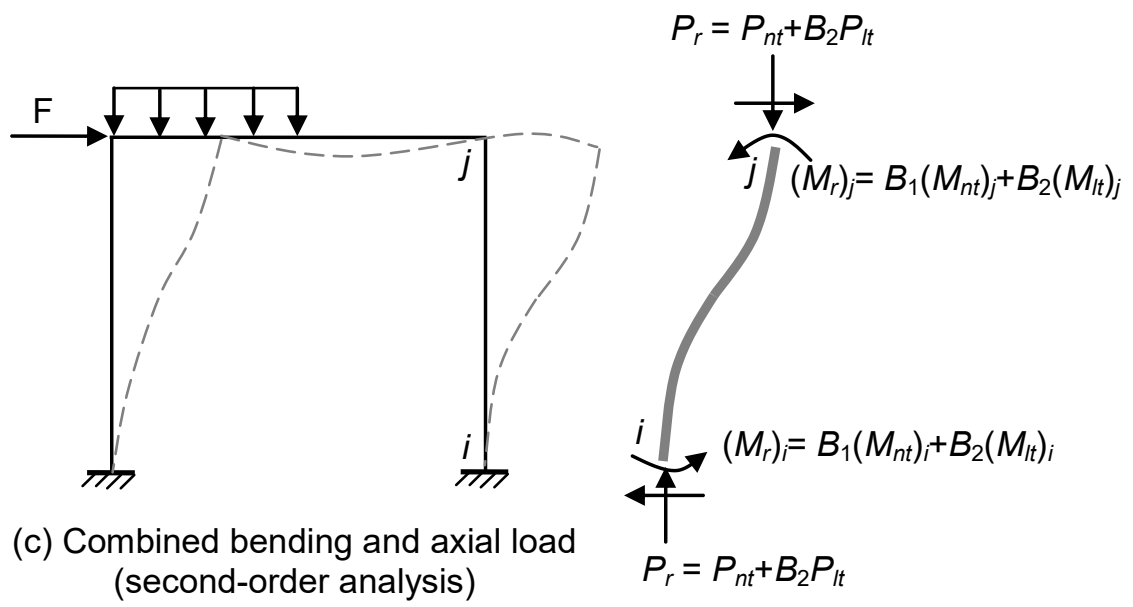

Fig. 4. $P_{r}$ and $M_{r}$ in beam-column design interaction equations 


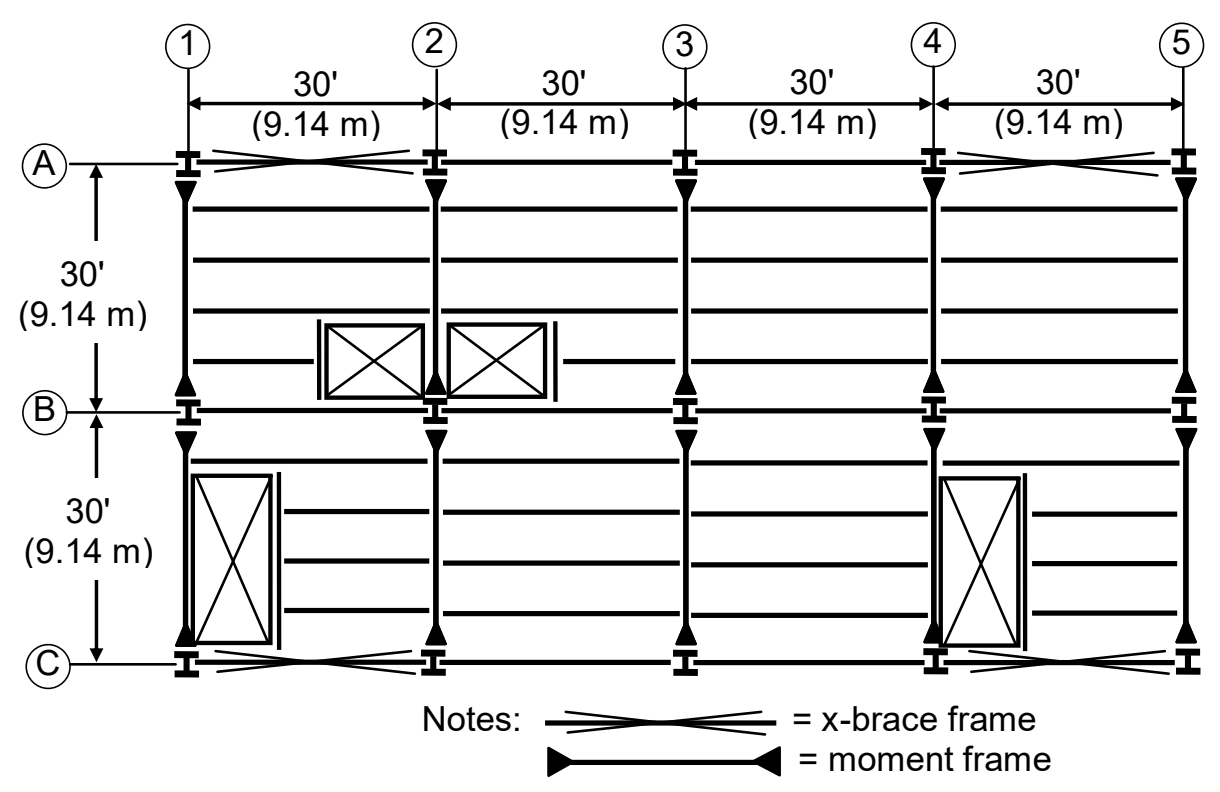

(a) Typical floor plan

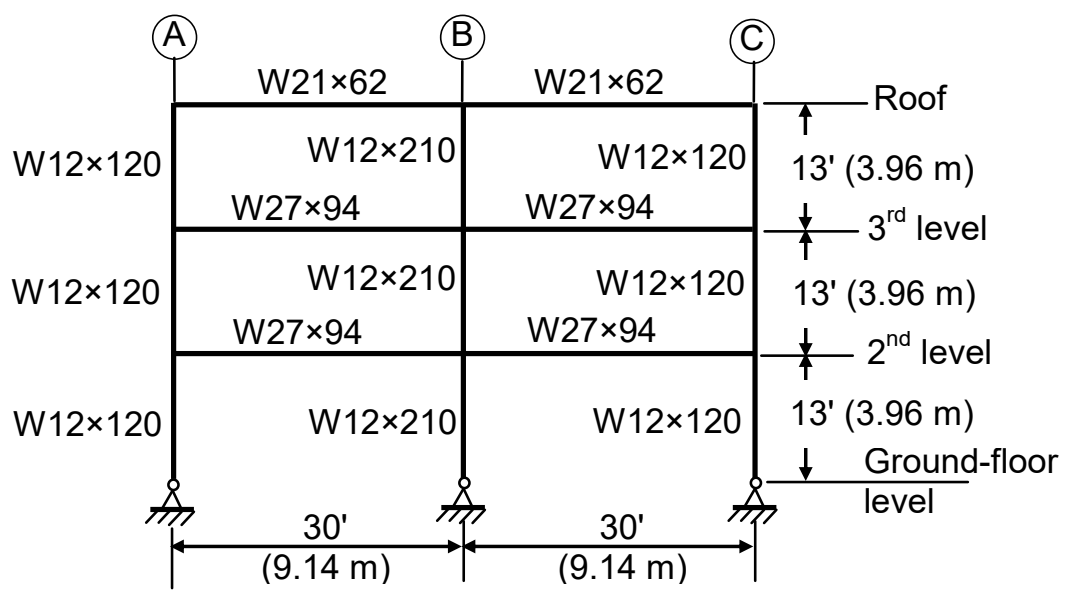

(b) Moment frame elevation at column line 3

Fig. 5. Typical floor plan and moment frame elevation for the design example 


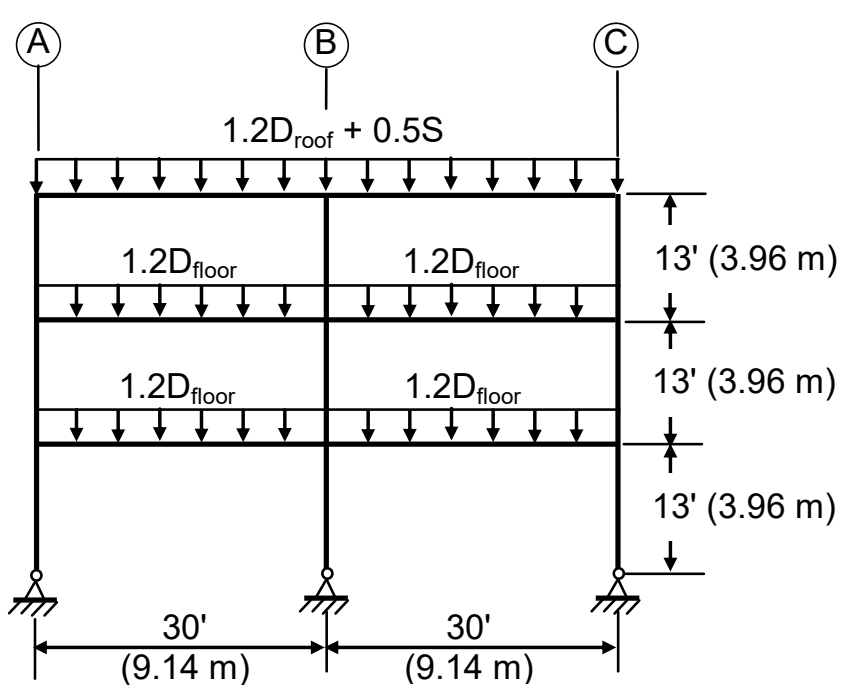

(a)

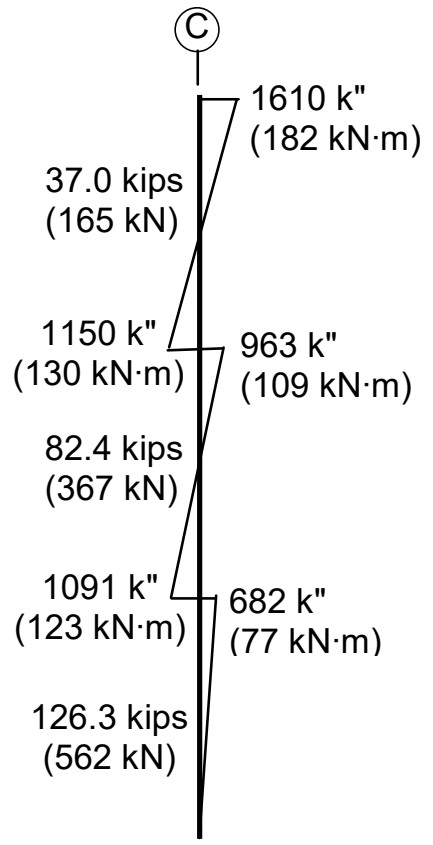

(b)

Fig. 6. Factored dead and snow loads 
(C)
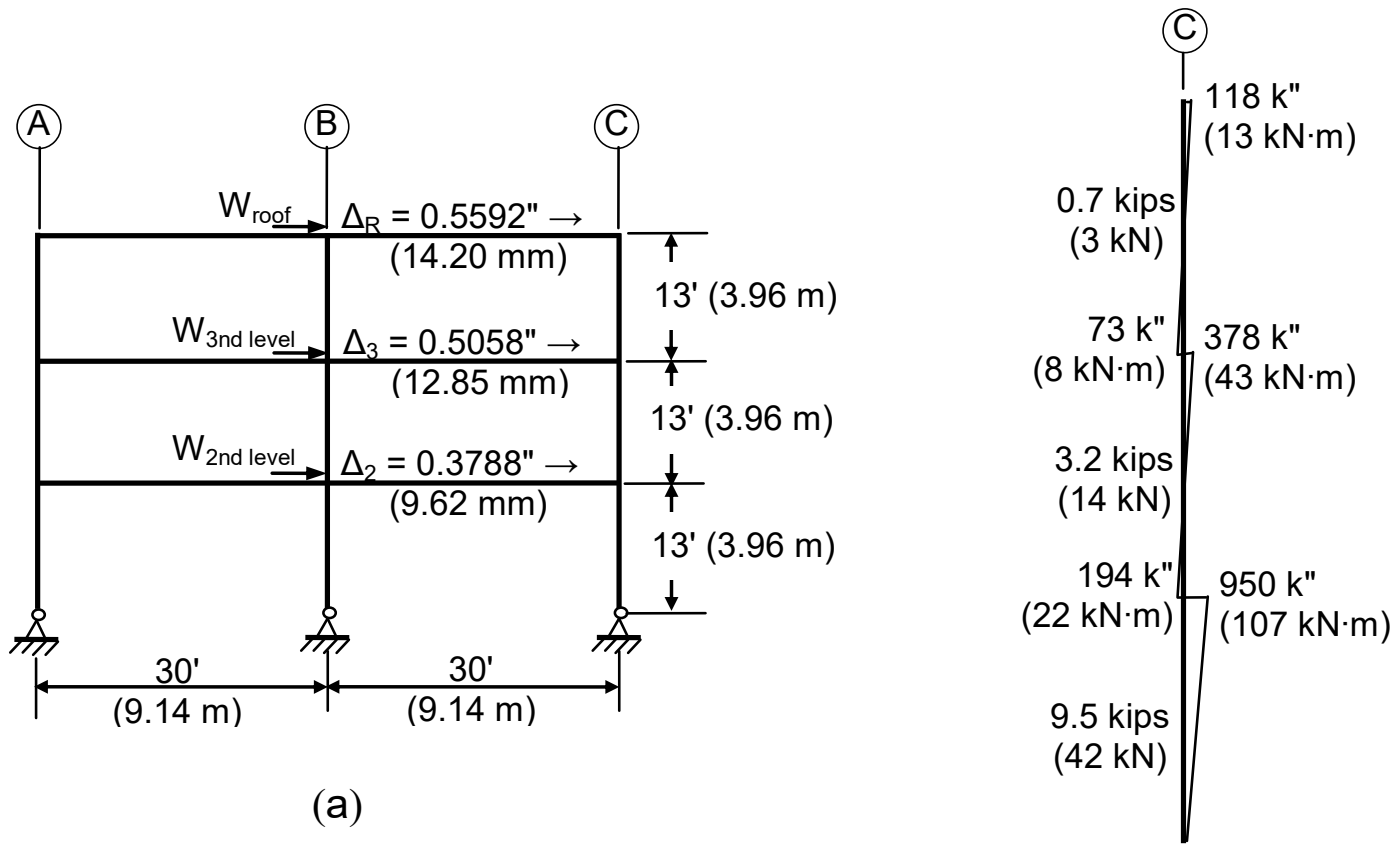

(a)

(b)

Fig. 7. Wind loads 


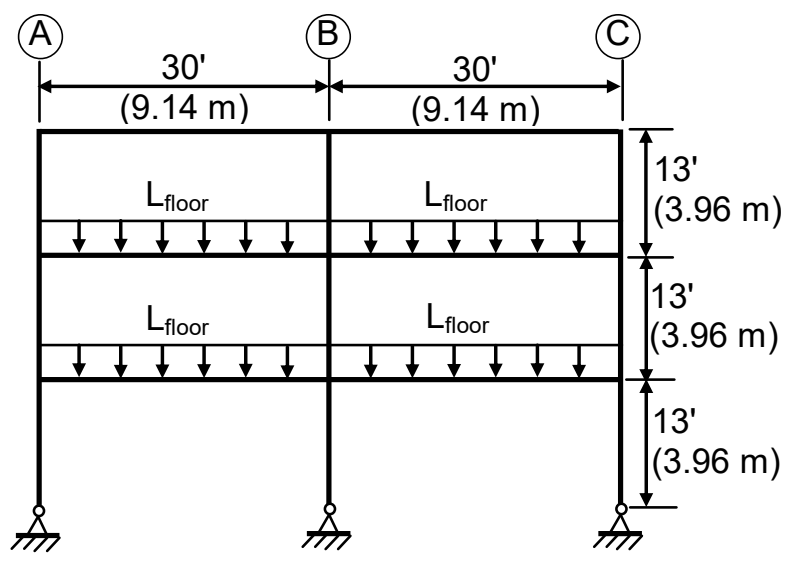

(a) Floor live load case (A): $L_{\text {case (A) }}$

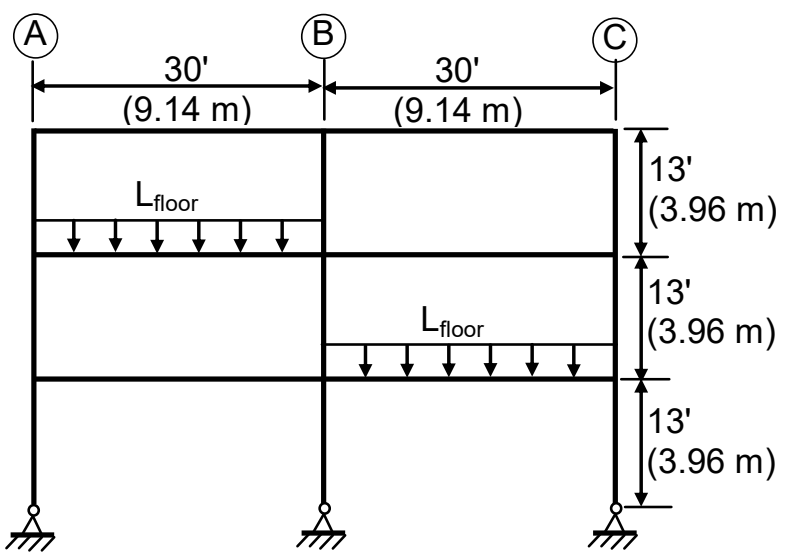

(b) Floor live load case (B): $\mathrm{L}_{\text {case }}(\mathrm{B})$

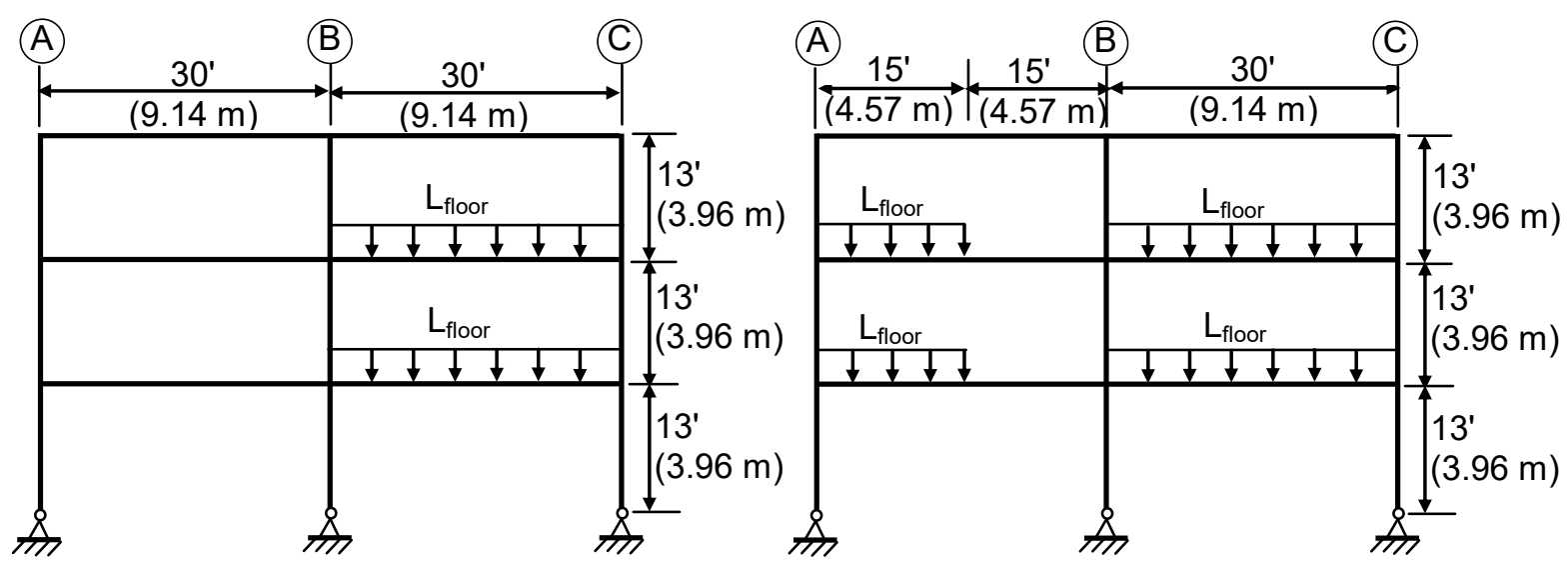

(c) Floor live load case (C): $L_{\text {case (C) }}$

(d) Floor live load case (D): $L_{\text {case (D) }}$

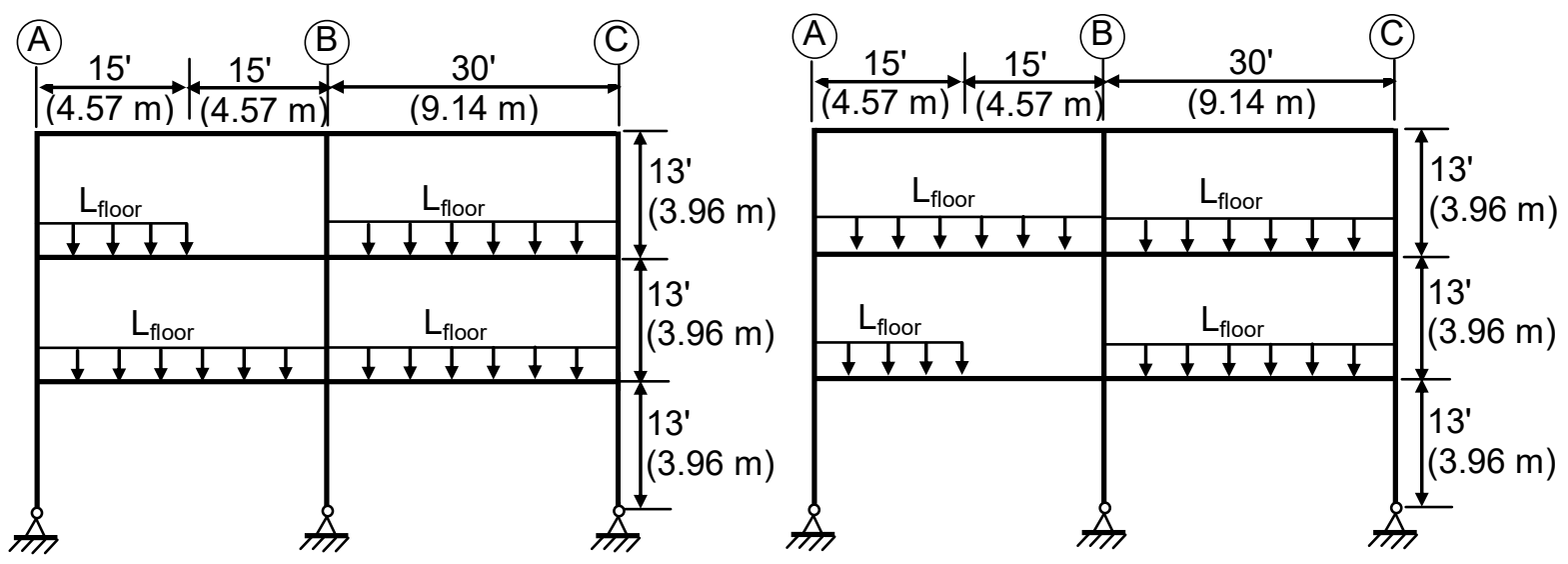

(e) Floor live load case (E): $L_{\text {case }(E)}$

(f) Floor live load case (F): $L_{\text {case }(F)}$

Fig. 8. Floor live load patterns 


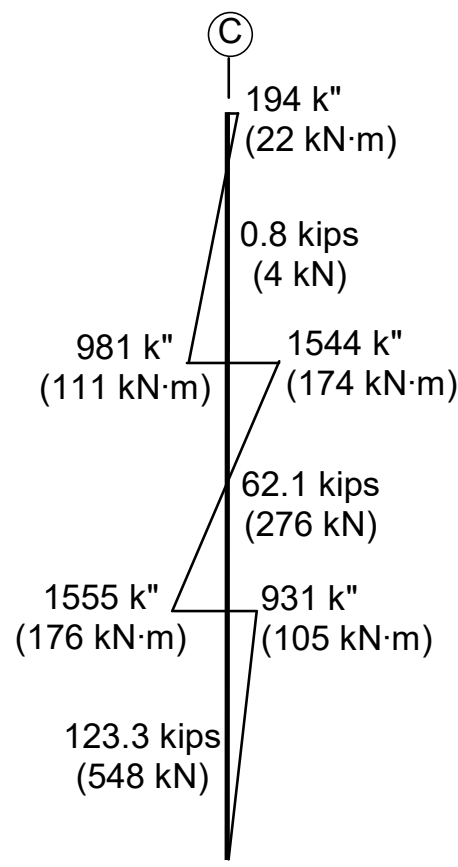

(a) $L_{\text {case (A) }}$

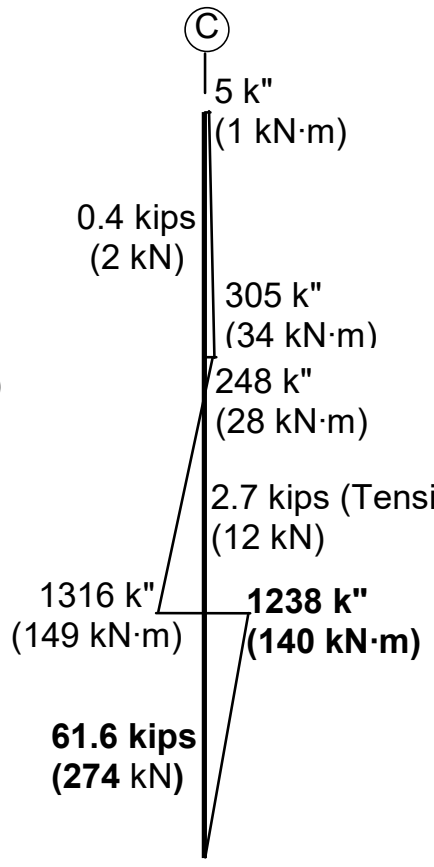

(b) $L_{\text {case (B) }}$

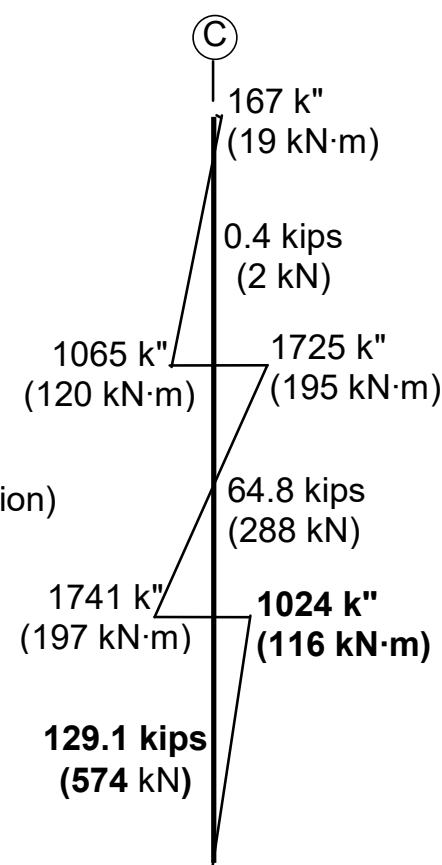

(c) $L_{\text {case (C) }}$
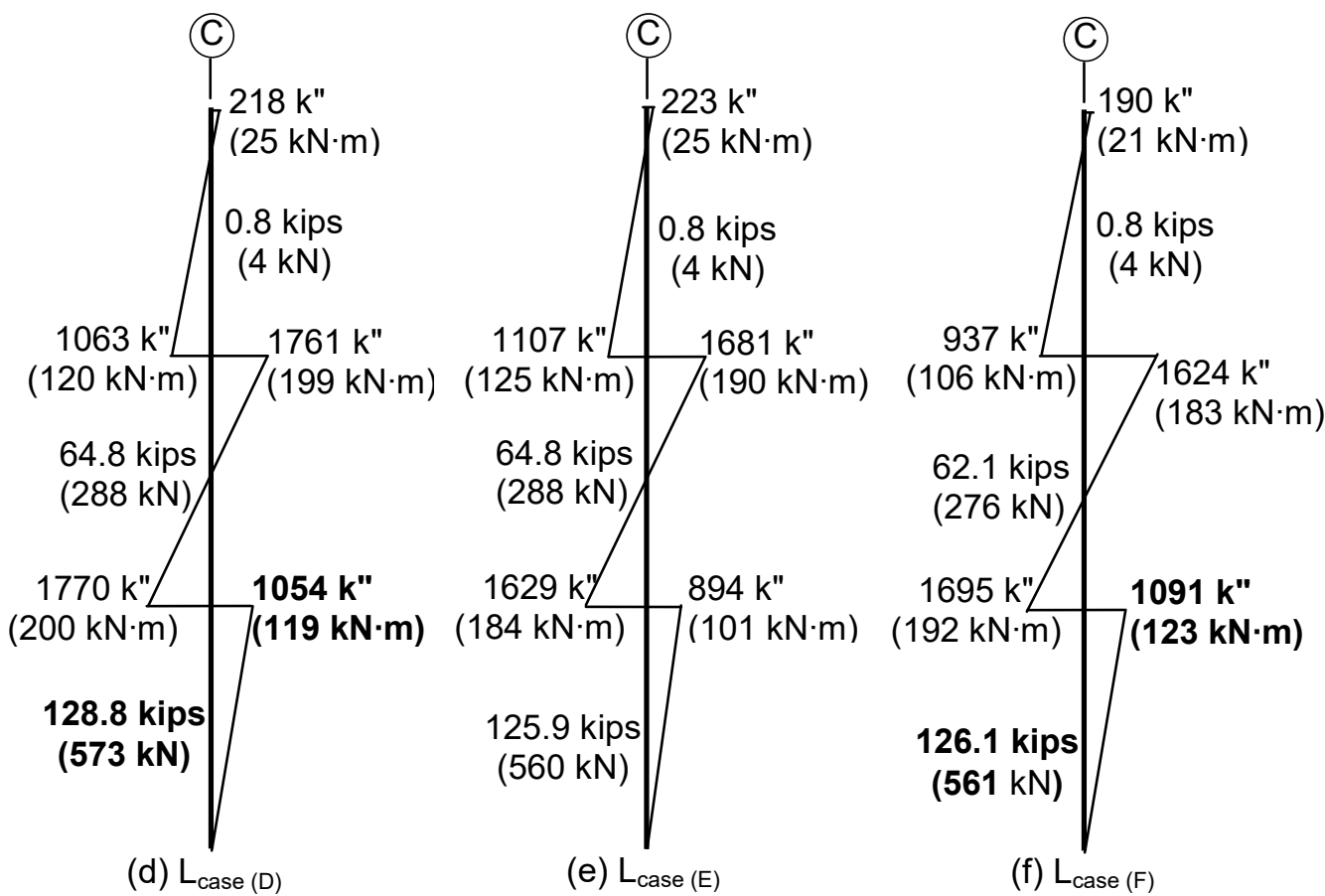

Fig. 9. Axial forces and end moments of the columns at column line $\mathrm{C}$ of the loaded frame shown in Fig. 8 


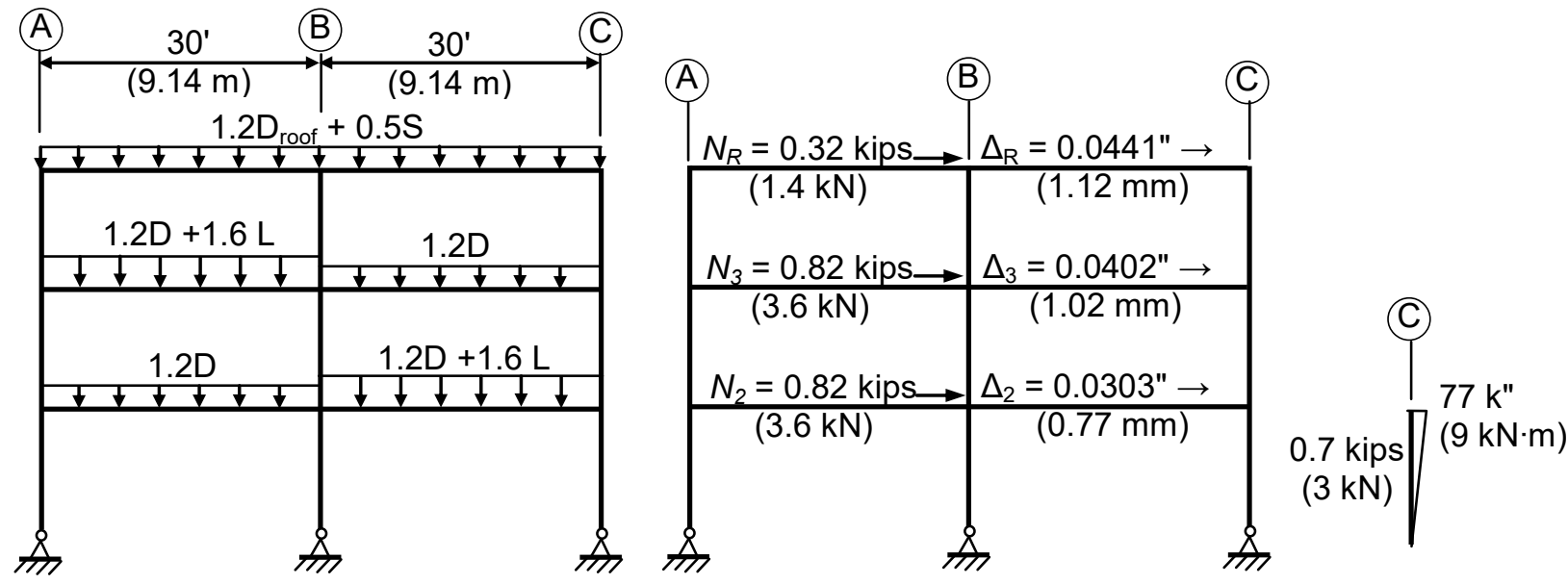

(a) Notional loads for $1.2 \mathrm{D}+1.6 \mathrm{~L}_{\text {case (B) }}+0.5 \mathrm{~S}$

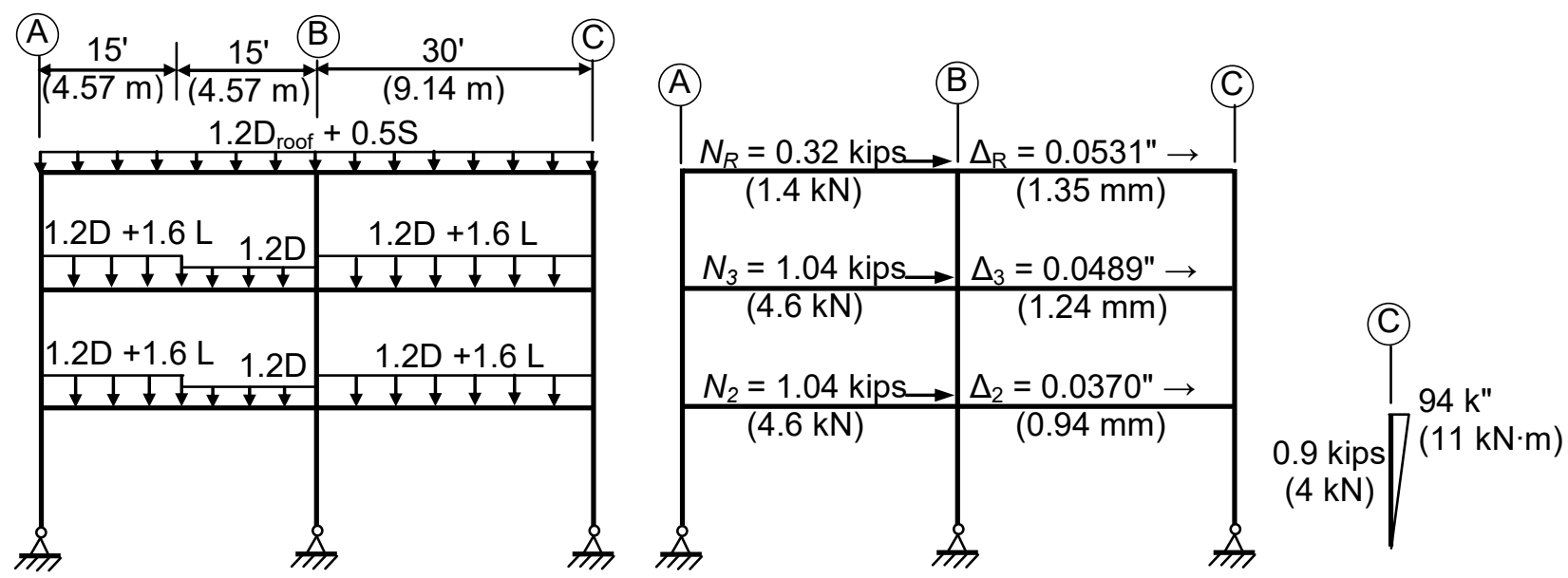

(b) Notional loads for $1.2 \mathrm{D}+1.6 \mathrm{~L}_{\text {case (D) }}+0.5 \mathrm{~S}$

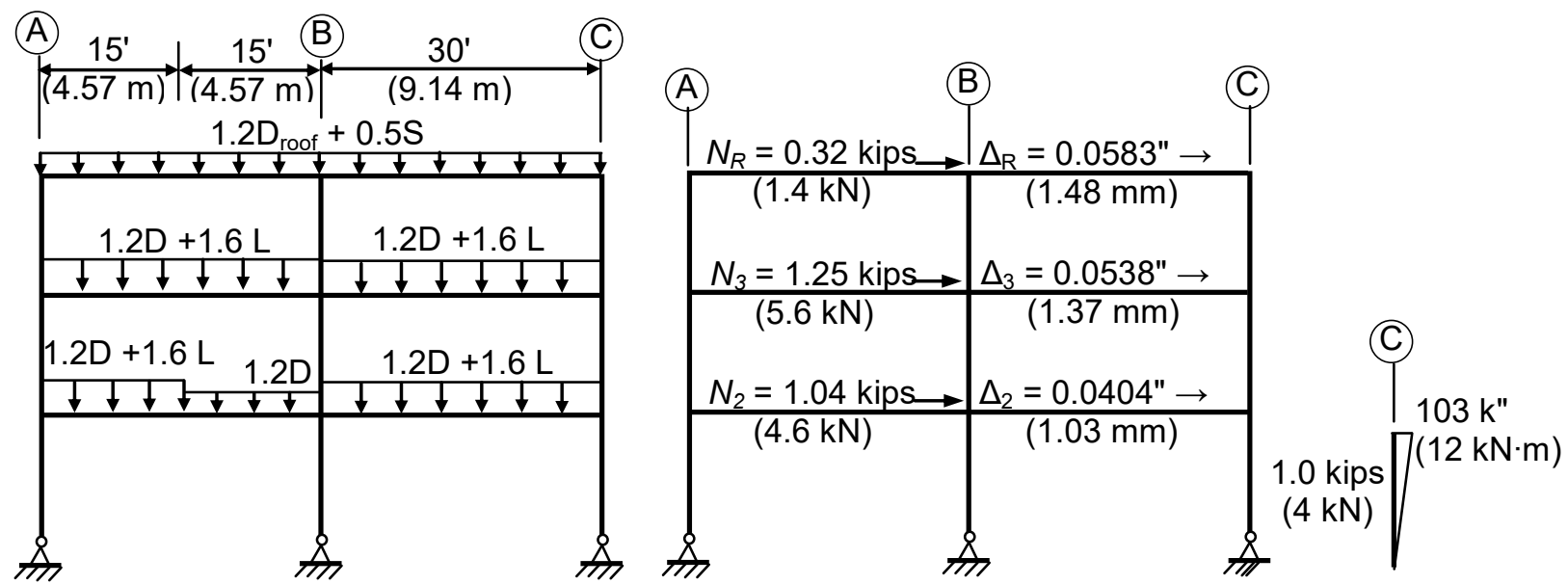

(c) Notional loads for $1.2 \mathrm{D}+1.6 \mathrm{~L}_{\text {case (F) }}+0.5 \mathrm{~S}$

Fig. 10. Notional loads 


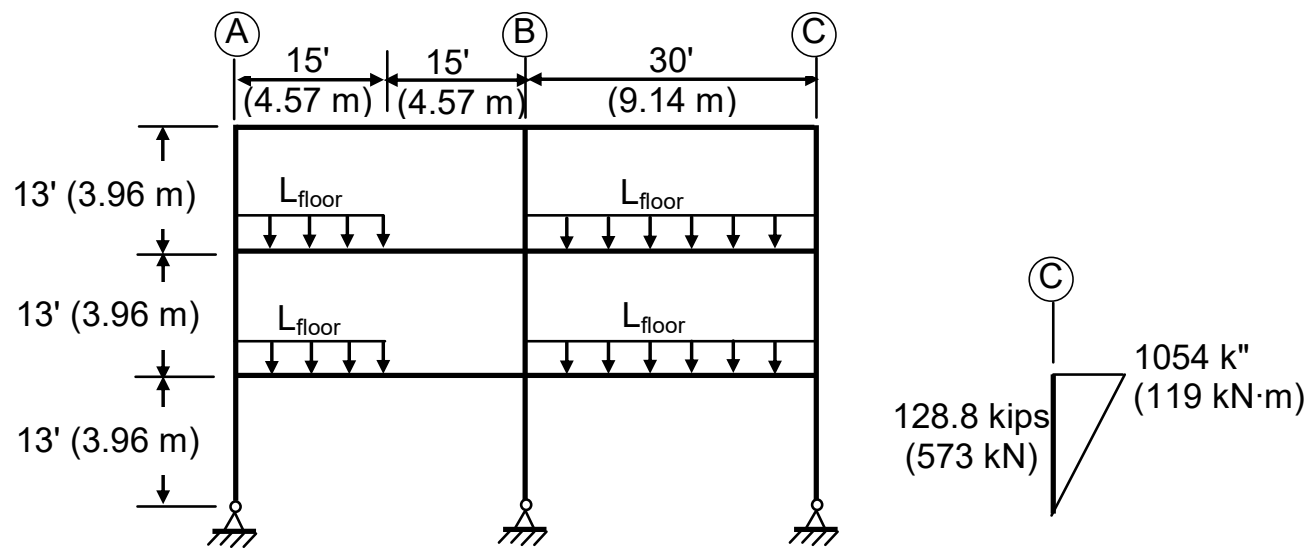

(a)

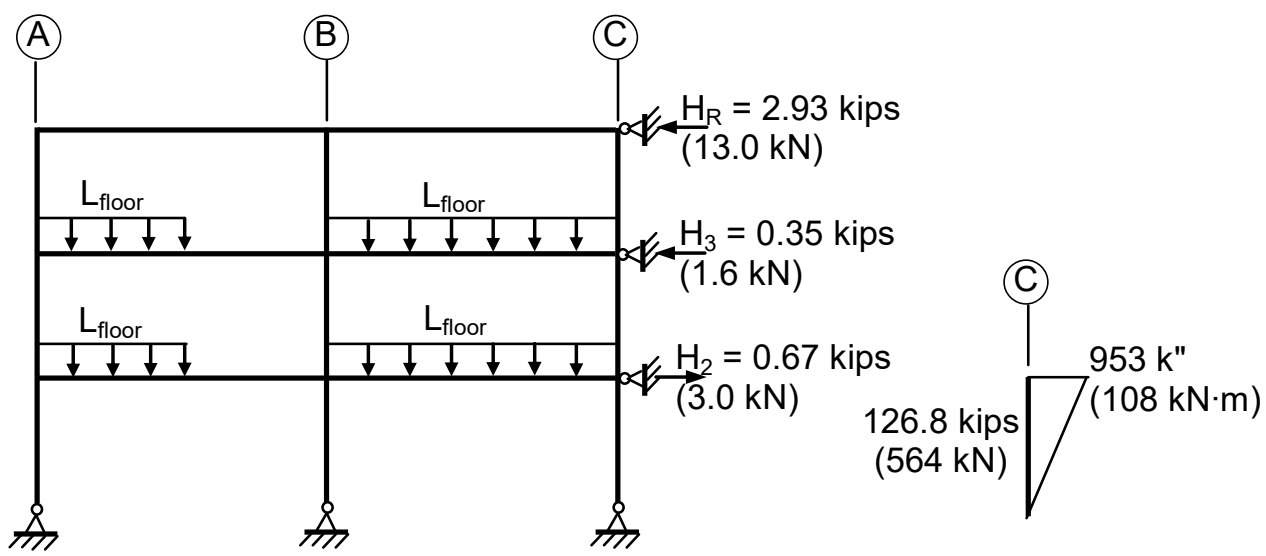

(b)

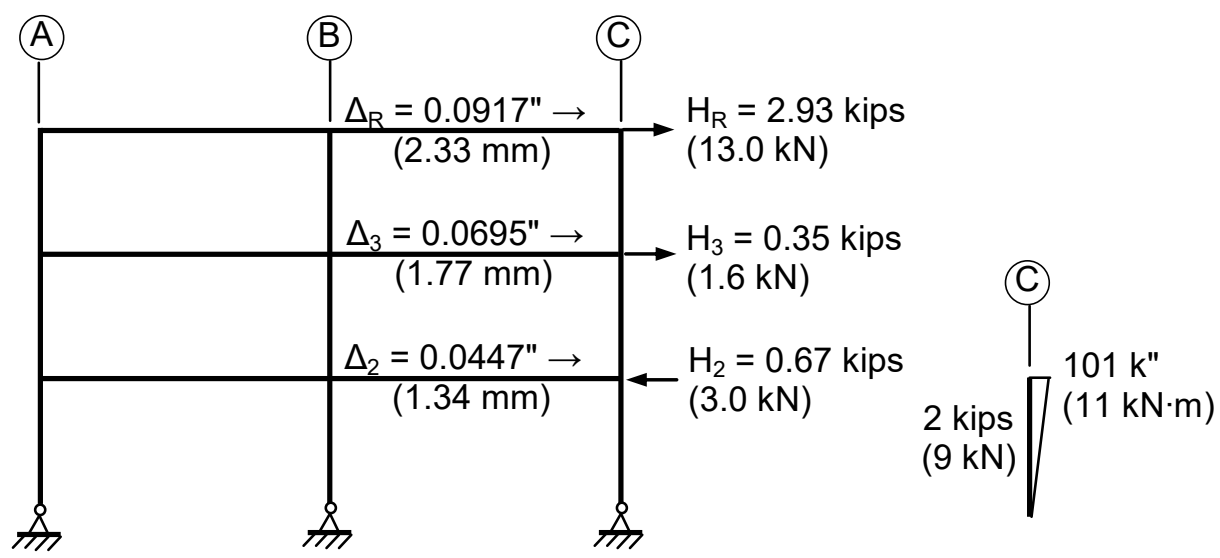

(c)

Fig. 11. Floor live load case (D) 

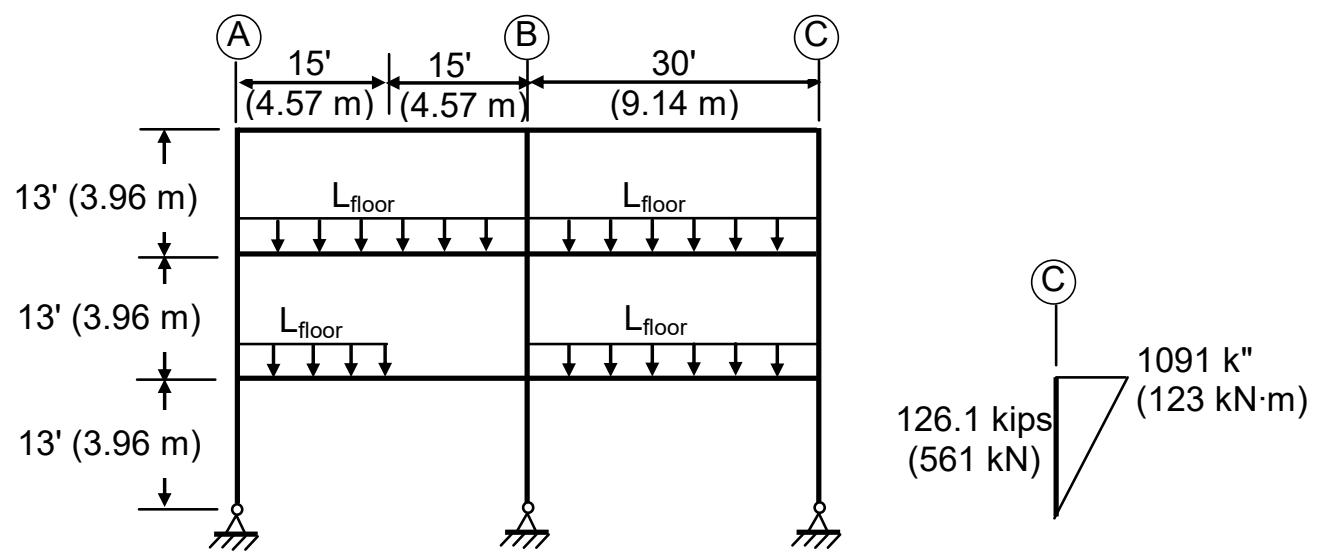

(a)

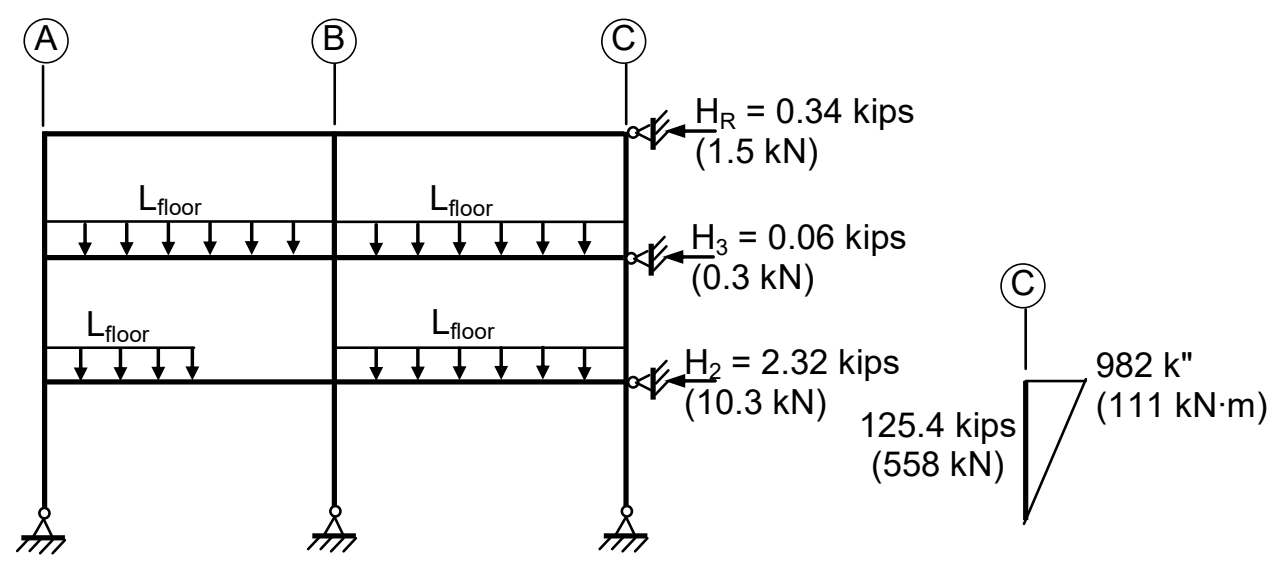

(b)

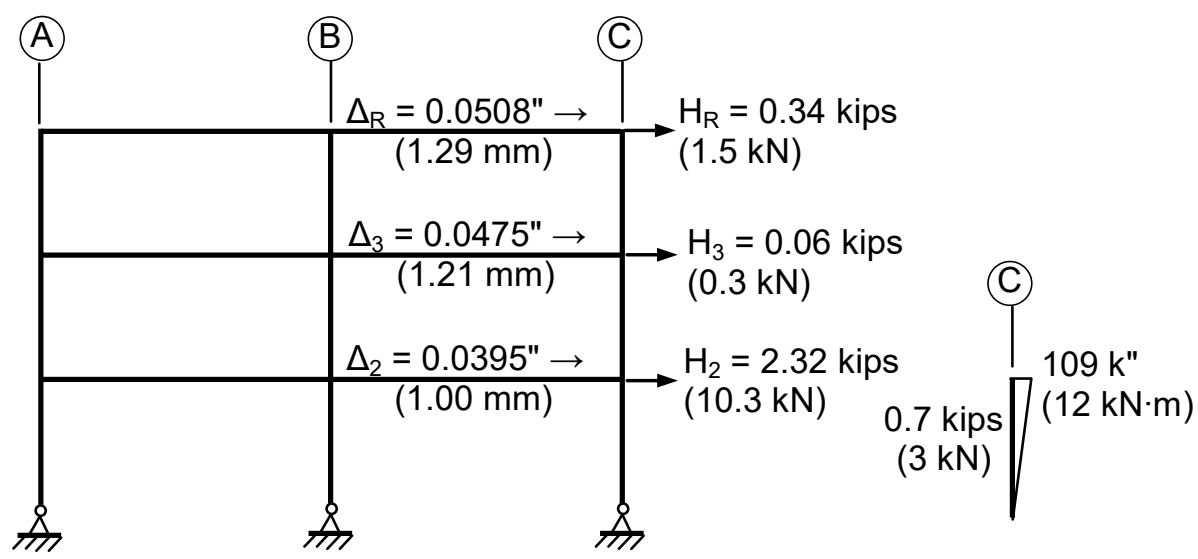

(c)

Fig. 12. Floor live load case (F) 


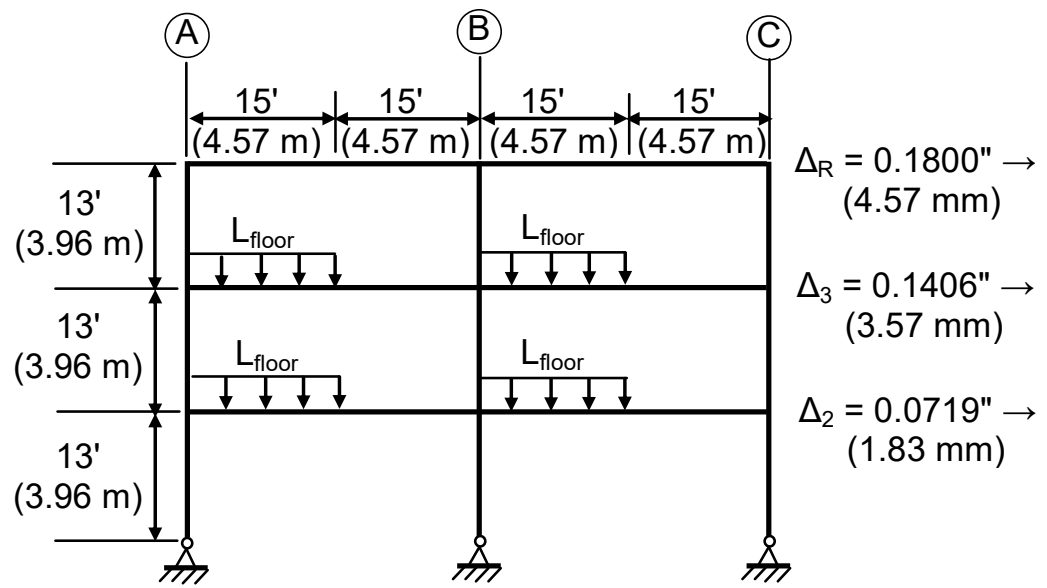

Fig. 13. The sidesway of the frame with all the floor spans are all partially loaded on the same side of the span 


\section{Citation}

Hsiao, J.K. (2018), "Partial-Span Live Loading Effects on the Design of Multi-Story Multi-Bay Steel Moment Frames," Practice Periodical on Structural Design and Construction, ASCE, Vol. 23, No. 4, pp. 04018020. possiblefraudstart "el.asce.org" possiblefraudend ascelibrary.org 